http://dx.doi.org/10.5800/GT-2013-4-4-0110

\title{
THE TECTONICS STRESS AND STRAIN FIELD MODELING ADJUSTED FOR EVOLUTION OF GEOLOGICAL STRUCTURES (SAILAG INTRUSION, EASTERN SAYAN)
}

\author{
V. N. Voytenko ${ }^{1}$, V. V. Pogorelov², A. O. Yakubovskaya ${ }^{3}$, A. V. Goneger ${ }^{3}$ \\ ${ }^{1}$ Saint Petersburg State University, Saint Petersburg, Russia \\ ${ }^{2}$ The Schmidt Institute of Physics of the Earth RAS, Moscow, Russia \\ ${ }^{3}$ Hoozhir Enterpise LLC, Ulan-Ude, Russia
}

\begin{abstract}
The article describes a tectonophysical model showing evolution of structures in the Sailag granodiorite massif in relation to its gold-bearing capacity. The model takes into account the load patterns according to geological data, accumulated deformation, and gravity stresses. This model provides for updating the structural-geological model showing development of the intrusion body and the ore field. Forecasted are destruction patterns in the apical and above-dome parts of the massif in the intrusion and contraction phase, formation of the long-term shear zone at the steeply dipping slope of the intrusion body, and subvertical fractures associated with the long-term shear zone and vertical mechanical 'layering' of the intrusive body.
\end{abstract}

Key words: intrusive complexes, digital simulation, gravity stresses, accumulated deformation.

Recommended by Yu.L. Rebetsky

Citation: Voytenko V.N., Pogorelov V.V., Yakubovskaya A.O., Goneger A.V. 2013. The tectonics stress and strain field modeling adjusted for evolution of geological structures (Sailag Intrusion, Eastern Sayan). Geodynamics \& Tectonophysics 4 (4), 419-433. doi:10.5800/GT-2013-4-4-0110.

\section{МОДЕЛИРОВАНИЕ ПОЛЯ ТЕКТОНИЧЕСКИХ НАПРЯЖЕНИЙ И ДЕФОРМАЦИЙ С УЧЕТОМ ЭВОЛЮЦИОННОГО ФОРМИРОВАНИЯ ГЕОСТРУКТУР (НА ПРИМЕРЕ САЙЛАГСКОГО МАССИВА, ВОСТОЧНЫЙ САЯН)}

\author{
В. Н. Войтенко ${ }^{1}$, В. В. Погорелов ${ }^{2}$, А. О. Якубовская ${ }^{3}$, А. В. Гонегер ${ }^{3}$ \\ ${ }^{1}$ Санкт-Петербургский государственный университет, Санкт-Петербург, Россия \\ ${ }^{2}$ Институт физики Земли им. О.Ю. Шмидта РАН, Москва, Россия \\ ${ }^{3}$ ООО «Хужир Энтерпрайз», Улан-Удэ, Россия
}

\begin{abstract}
Аннотация: Рассмотрена тектонофизическая эволюционная модель развития структур Сайлагского массива гранодиоритов в связи с его золотоносностью. В эволюционной модели учтены схема нагрузки по геологическим данным, гравитационные напряжения и накопленные деформации. В результате моделирования была уточнена структурногеологическая модель развития интрузива и рудного поля. Спрогнозированы структуры разрушения в апикальной и
\end{abstract}


V.N. Voytenko et al.: The tectonics stress and strain field modeling...

надкупольной частях массива на этапе внедрения и остывания интрузии. Спрогнозировано формирование долгоживущей зоны сдвига на крутопадающем склоне интрузии и сопряженных субвертикальных разрывных нарушений, вертикальной механической «расслоенности» интрузивного тела.

Ключевые слова: интрузивные комплексы, численное моделирование, гравитационные напряжения, накопленные деформации.

\section{1. ВВЕДЕНИЕ}

Моделирование поля тектонических напряжений и деформаций с учетом эволюционного формирования геологических структур - актуальное направление в области использования законов механики для изучения масштабных участков земной коры - тектонофизики. Численное моделирование позволяет учитывать такую важную величину, как сила гравитации, которая многими исследователями не принималась во внимание из-за отсутствия возможности оценить ее влияние на количественном уровне. С другой стороны, именно традиционное геологическое исследование и выявление истории геологического развития региона (эволюции нагрузки геологических структур) дают первичные необходимые параметры (размеры геологических тел, последовательность деформаций и пр.) для тектонофизического моделирования. В итоге, комплексное, наиболее приближенное к реальным объектам, тектонофизическое моделирование может исправлять или уточнять влияние того или иного фактора в геологических моделях развития структур рудных полей и месторождений.

В последние годы в юго-восточной части Восточного Саяна выявлен ряд месторождений (в том числе Коневинское месторождение), относимых к золотопорфировому типу. Гранитоиды, вмещающие оруденение, относят к I-типу, а формирование интрузивных комплексов - к обстановкам островных дуг и активной континентальной окраины, существовавших в байкальское и каледонское время соответственно [Zhmodik et al., 2006].

Коневинское месторождение расположено в Сайлагском интрузиве порфировидных монцо-гранодиоритов Таннуольского комплекса в южной части Хамсаринской структурно-фациальной зоны, в 7.5 км к северу от ее южной границы, проходящей по субширотному Жомболокскому глубинному разлому. Массив имеет изометричную форму в плане, слегка вытянутую в широтном направлении, размеры массива $12 \times 7$ км. Сайлагский интрузив внедрен в карбонатные породы иркутной свиты, в западной части массива наблюдаются отложения вулканогенно-осадочной илейской свиты, с размывом залегающей на интрузивном массиве и на породах иркутной свиты. Возраст массива соответствует 450-480 млн лет [Fedotova, Khain, 2002].
Если вещественный состав руд месторождений золотопорфирового и золотокварцевого типов, а также вмещающих их пород достаточно детально охарактеризован [Gromov et al., 2011; Zhmodik et al., 2006; Roshchektaev et al., 2000], то структуры интрузивов, контролирующих оруденение, изучены слабо. С целью уточнения формирования структур в пределах Сайлагского массива, в связи с его золотоносностью, было проведено двухмерное численное моделирование интрузива и вмещающей его рамы, что позволило скорректировать структурно-тектоническую модель развития, основанную только на геологических наблюдениях [Gromov et al., 2011].

\section{2. ОПИСАНИЕ МОДЕЛИ}

Конечно-элементная модель двухмерного профиля через Сайлагский массив, ориентированного в направлении юг-север, построена на основе структурно-тектонической модели с учетом прочностных параметров по результатам петрофизических исследований пород массива. Структура профиля представлена на рис. 1. Описание материалов и механические параметры модельной среды вдоль структурного профиля приведены в таблице.

Предложенный разрез имеет прямоугольную форму, размеры составляют $6 \times 9$ км при анализируемой области $3 \times 5$ км (пунктир). Цифрами в кружках отмечены номера структурных областей модели (таблица, столбец 11). Границы раздела карбонатных пород и интрузивного тела имеют различный наклон $\left(13^{\circ}\right.$ и $28^{\circ}$ ), что отражено в геометрическом строении внутренних областей 5 и 1 (рис. 1). Верхний горизонтальный блок схематически отображает осадочные отложения, полностью эродированные на начальных стадиях формирования структуры. Их влияние на формирование напряженно-деформированного состояния задавалось дополнительной распределенной по поверхности нагрузкой переменного во времени значения. Нижние области (6-7) предназначены для компенсации граничных условий, а также создания дополнительных предпосылок для проседания центральной части разреза.

Реологическая модель геоматериала описывалась упруго-пластическим телом Друккера-Прагера для 


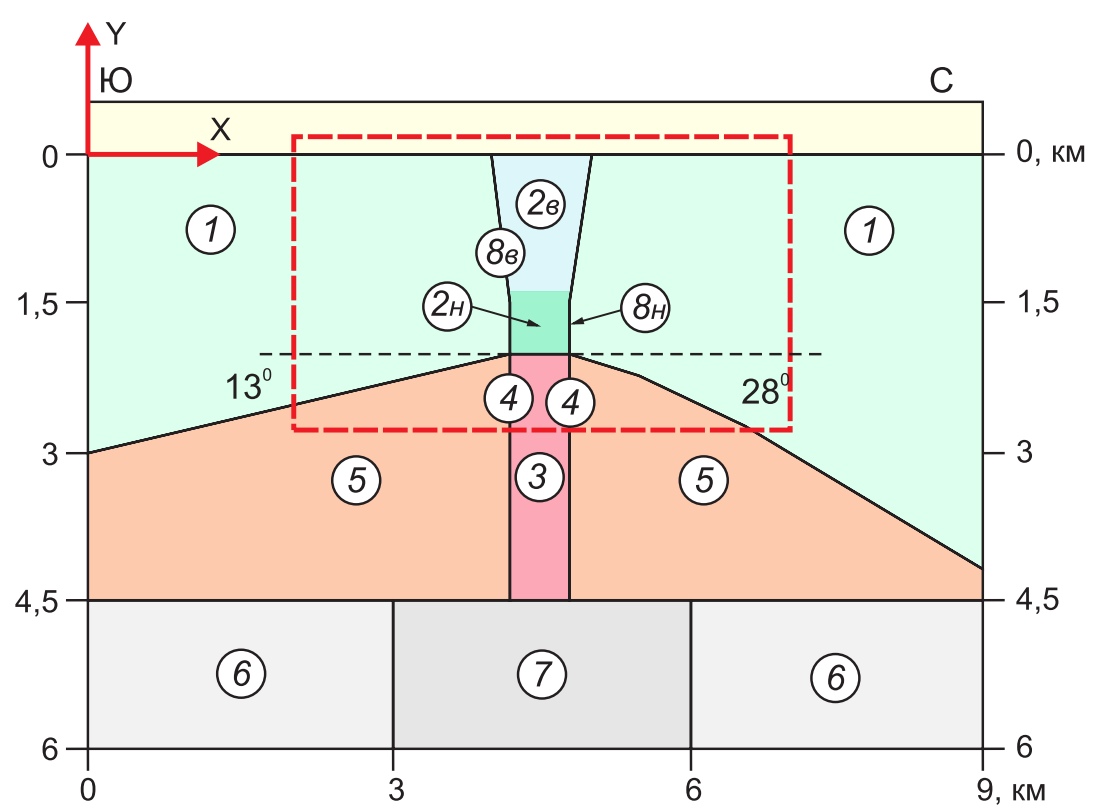

1-3 - карбонатные породы;

3, 5 - гранодиоритовая интрузия;

6-7 - основание (структурный слой);

4 - разрывное нарушение

в гранодиоритах (кварцевая жила);

8 - разрывное нарушение

в карбонатах (кварцевая жила);

Рис. 1. Структура расчетного профиля интрузивного массива.

Описание материалов и механические параметры модельной среды вдоль структурного профиля приведены в таблице. Пунктирный прямоугольник - анализируемая область (3×5 км).

Fig. 1. The structure of the calculated profile of the intrusive massif.

See Table for the description of materials and mechanical parameters of the structural model along the profile. The area under study ( $3 \times 5 \mathrm{~km})$ is marked by the red box.

основных анализируемых структур и телом Мизеса (таблица, столбец 7) для структурного нижнего слоя, а также для интрузии на стадии внедрения [Pogorelov et al., 2010; Rebetskiy, 2008]. Плотностные и механические свойства основных материалов, а также условия нагрузки менялись в соответствии с геологической эволюционной моделью формирования структуры Сайлагского массива (рис. 2, $a ; 7, a)$ : вертикальное внедрение и остывание массива; размыв; горизонтальное растяжение, однородное по вертикали; формирование депрессий и наложенных разрывов; горизонтальное сжатие. Линеаризованные области (кварцевые жилы), обрамляющие центральную область вмещающей рамы, определяют разломные зоны, активизирующиеся на заключительных стадиях нагружения и описывающиеся телом Друккера-Прагера с пониженным пределом прочности. Предполагалось, что данные элементы будут «работать на сдвиг» при проседании центральной части модели (рис. 5, a). Численное моделирование проводилось с использованием конечноэлементного вычислительного комплекса UWAY [Vlasov et al., 2004]. Основным преимуществом модели, построенной в комплексе UWAY, в отличие от предшествующих эволюционных моделей внедрения интрузивов (например [Belov, 1993]), является возможность учитывать массовые силы и накопленные деформации.

На основе разработанной эволюционной геологиче- ской модели [Gromov et al., 2011] была рассмотрена следующая схема нагружения (рис. 2, б; 7, б). Первая стадия представляет собой накопление начальных деформаций и поле напряжений под воздействием начального гравитационного состояния (рис. 2, б). Интрузия на начальной стадии внедрения характеризуется слабосжимаемым геоматериалом (коэффициент Пуассона $v=0.35$, таблица, ст. 6), подверженным интенсивному катакластическому течению (тело Мизеса, низкий предел текучести).

На второй стадии (рис. 3, б) происходит застывание верхних слоев интрузивного внедрения, что характеризуется изменением значения $v$ до 0.27. Более податливая нижняя часть интрузии продолжает внедрение (создает небольшое дополнительное давление вверх (рис. 3, б)). Эрозионный размыв на данной стадии приводит к уменьшению распределенной нагрузки на верхнюю границу вдвое.

На первой и второй стадиях структурные области в пределах однотонной заливки (рис. 2, б; 3, б) однородны, как и прямоугольный нижний блок в центральной части. На вертикальных границах допускается деформирование по вертикальной оси системы координат, связанной с плоскостью разреза. Перемещения на этих границах по горизонтали отсутствуют.

Третья стадия (рис. 4, б) характеризуется региональным горизонтальным растяжением, амплитуда которого достоверно не известна. Предполагается, что за 


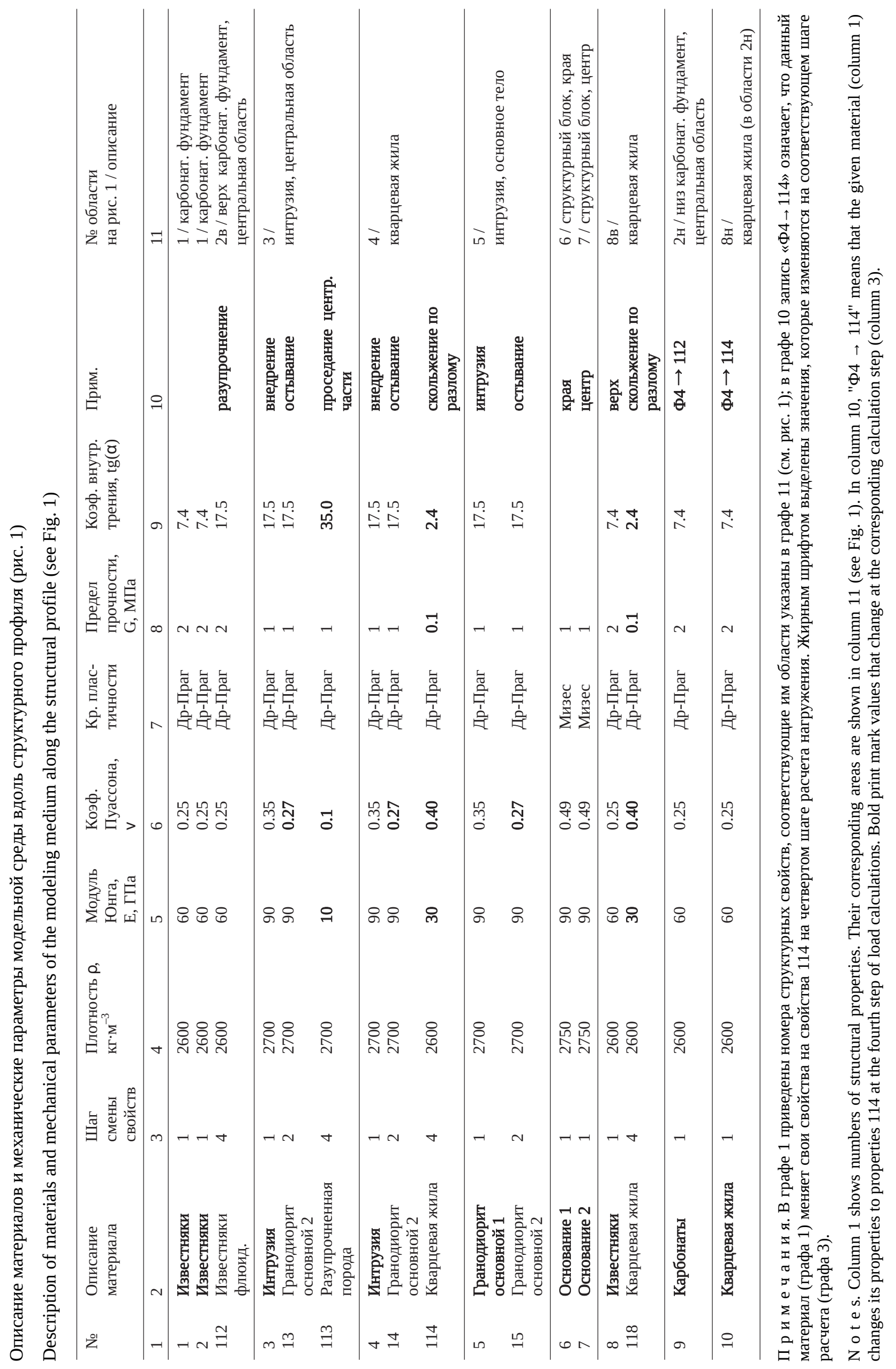


()

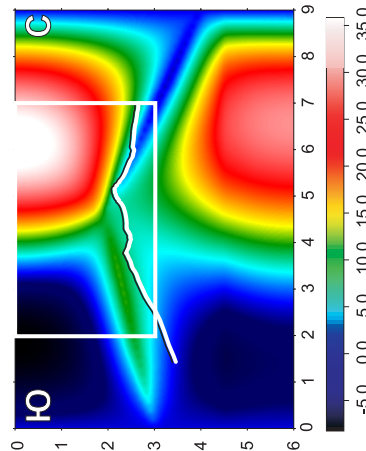

$\ominus$

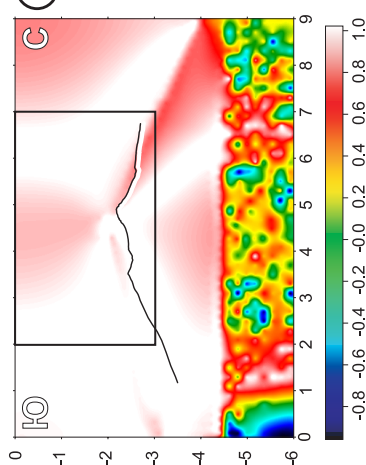

nеtreH-ətou कеок $\odot$

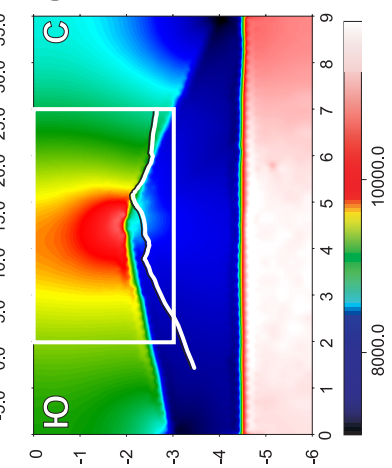

())

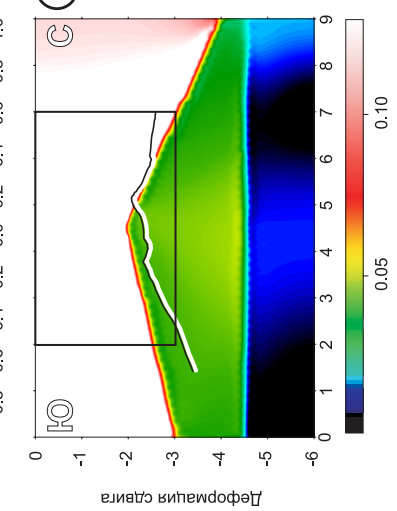

$\infty$

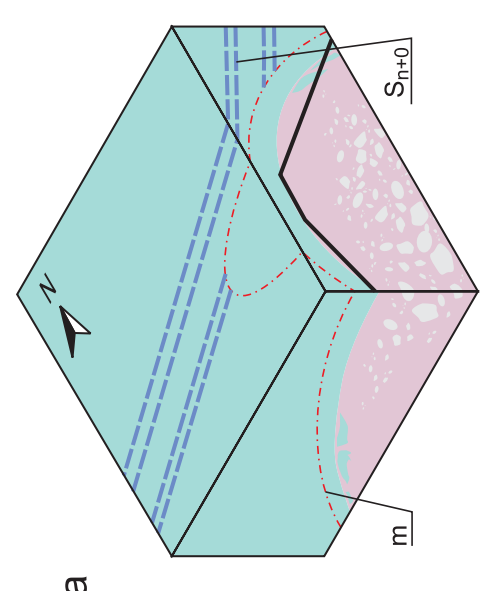

()

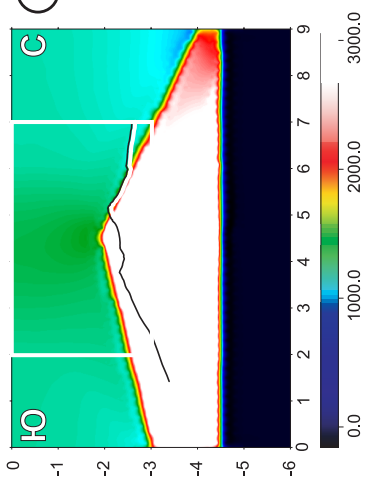

(4)

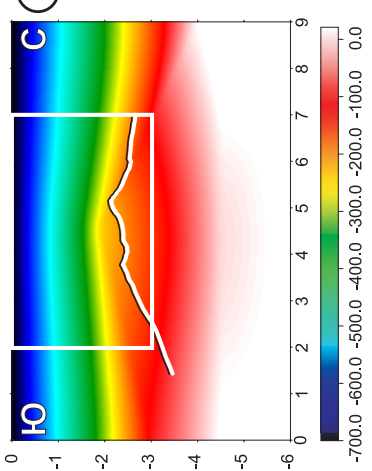

w 'ьинәтпәшәdəu әІянवчехицdəg

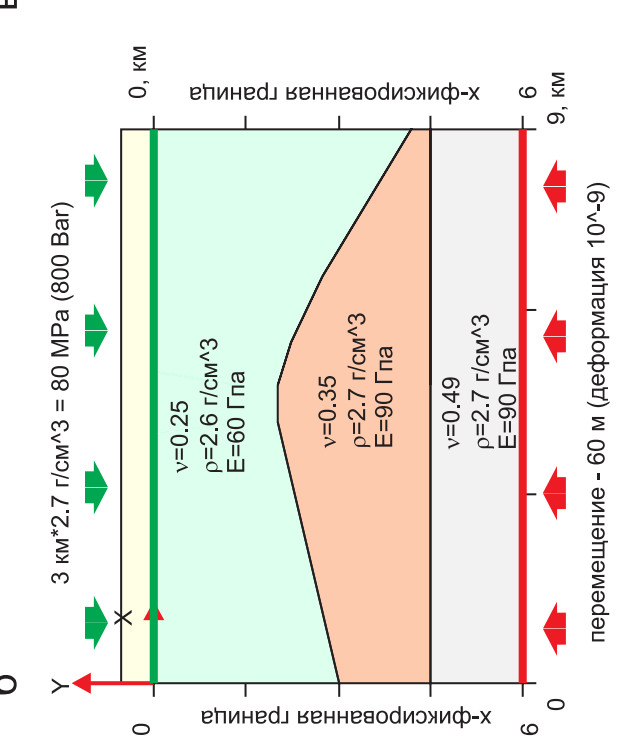

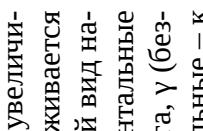

空管

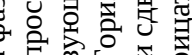

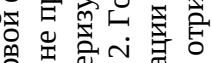

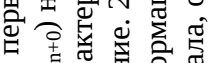

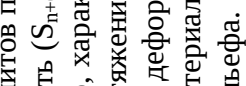

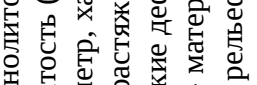

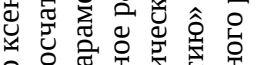

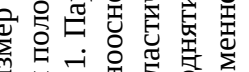

क्ष

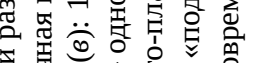

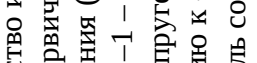

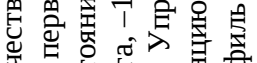

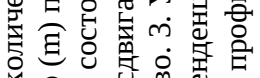

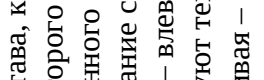

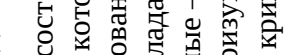

융 差

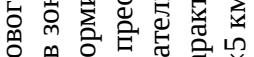

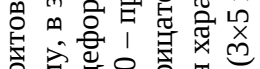

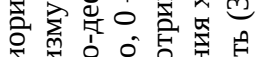

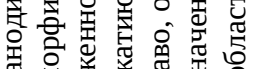

尊

政

을

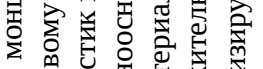

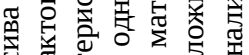

旸

至

6 6

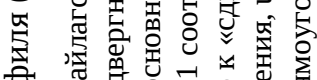

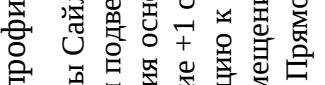

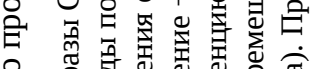

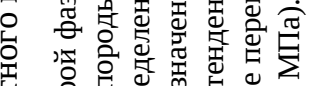

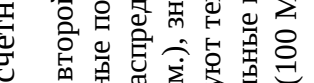

品

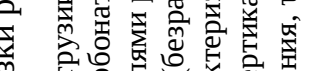

旁

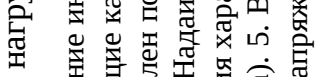

要

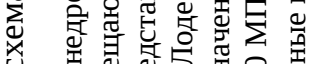

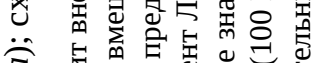

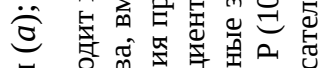

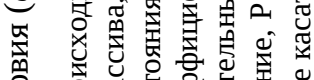

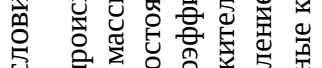

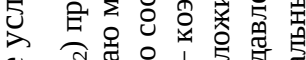

要

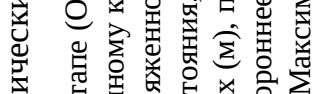

居

它

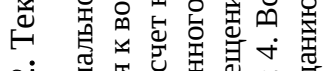

ن 层

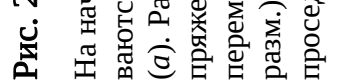

을 줄

은

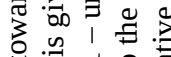

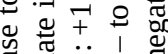

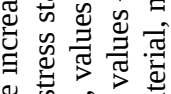

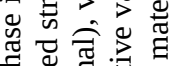

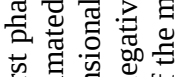

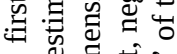

送要

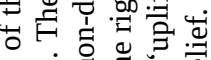

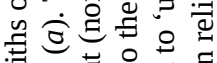

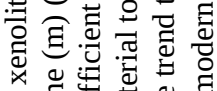

郭

눙

穿.

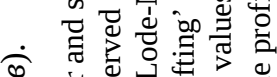

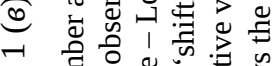

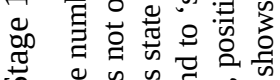

in 0

边

诺

की

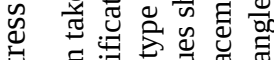

究

要

응

क

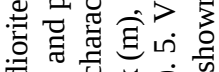

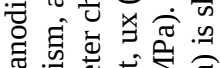

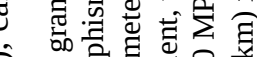

6

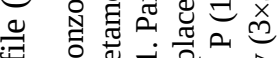

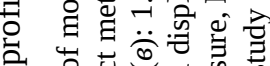

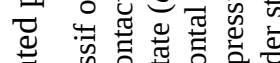

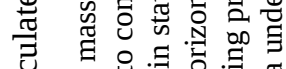

त्

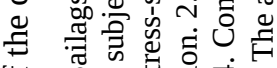

पे

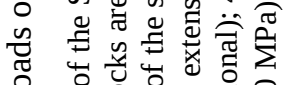

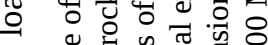

to 0

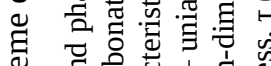

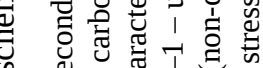

势

은

जิ

o 음

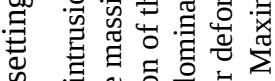

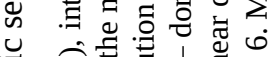

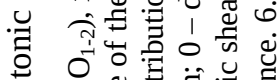

过 0

i 嘼

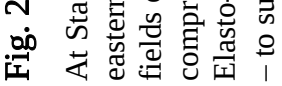


(2)

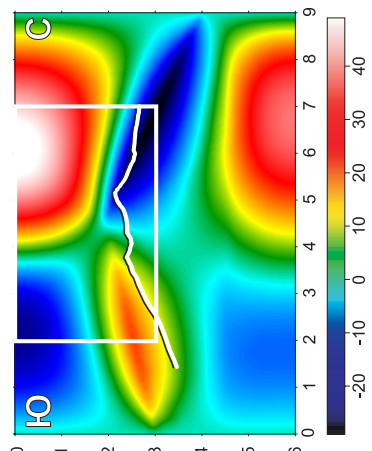

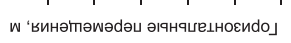

$\ominus$

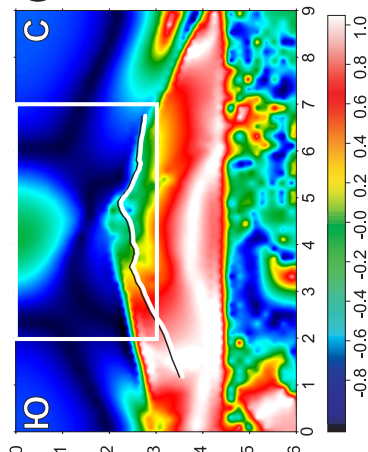

иетен-әtог 'феск $\odot$

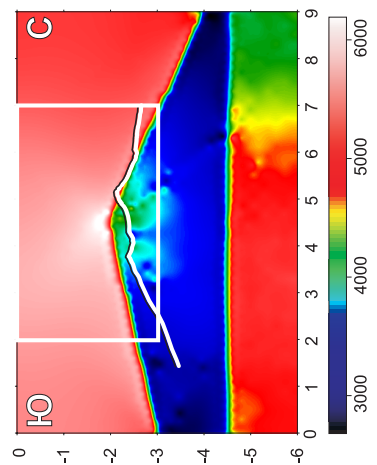

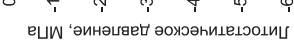

().
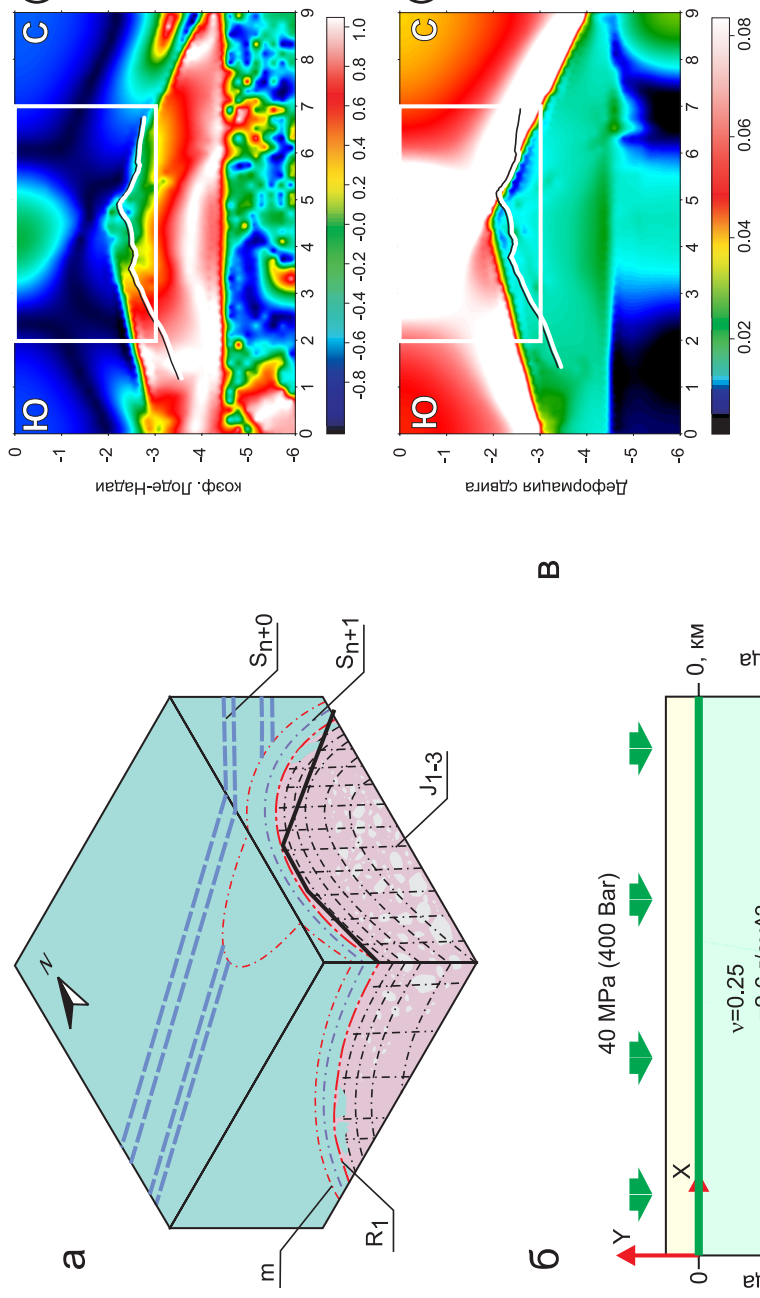

$\infty$

().

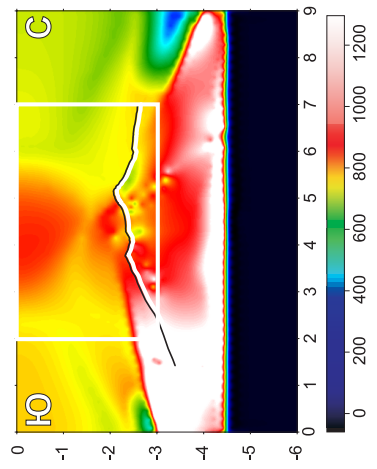

(4)
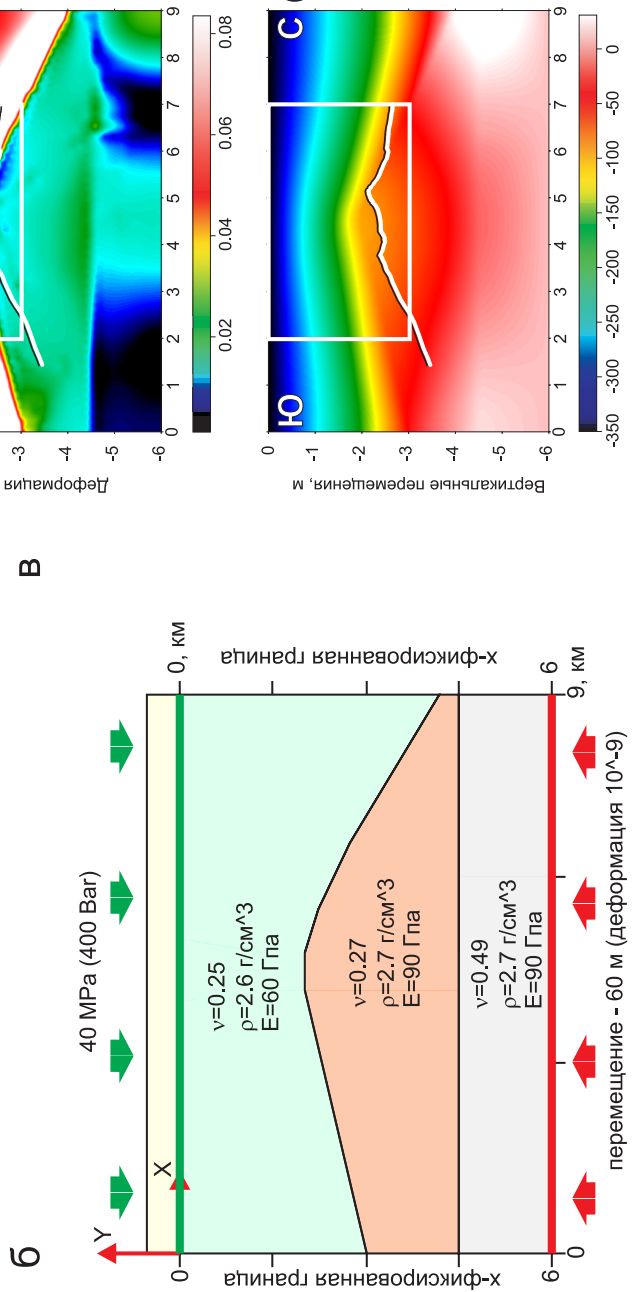

(ิ)

苨

응

命

突

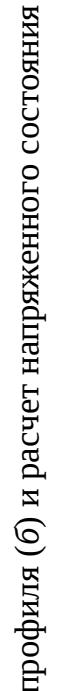

0

온

苞

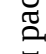

ले

究

$\sum_{0}^{\pi}$

$\sum_{\substack{0 \\ ن}}$

$\ddot{\sigma}$

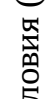

गे

봉

苞

ت্ّ

t.

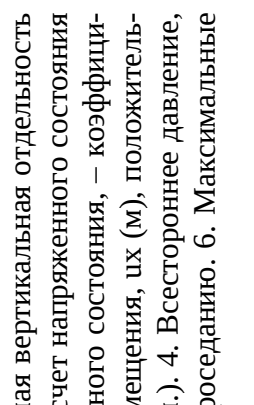

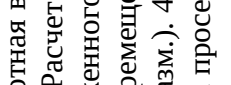

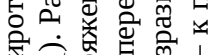

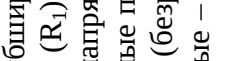

记

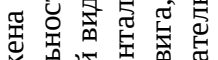

有 瓷

言客言

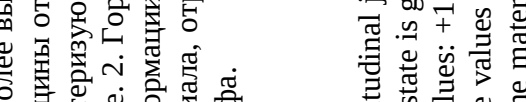

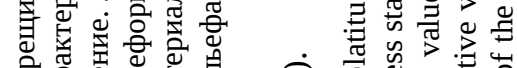

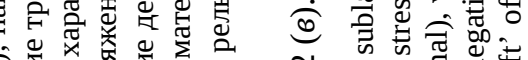

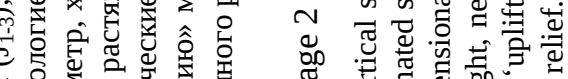

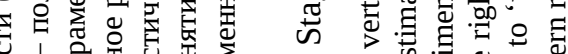

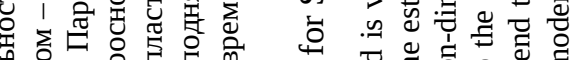

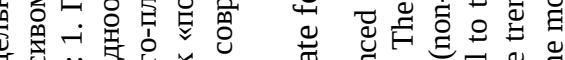

客蒙前i

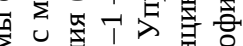

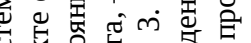

尊

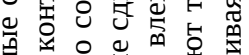

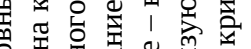

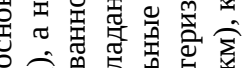

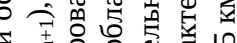

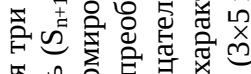

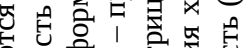

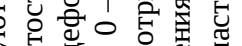

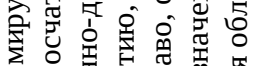

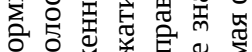

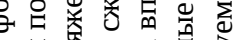

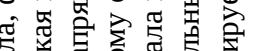

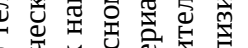

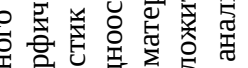

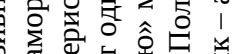

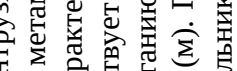

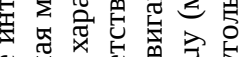

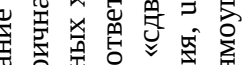

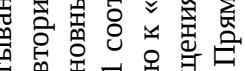

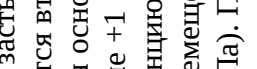

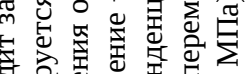

等

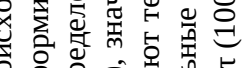

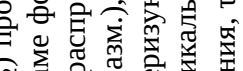

政

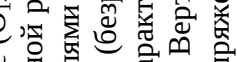

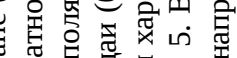

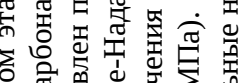

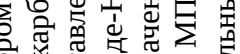

응

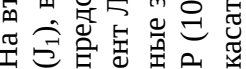

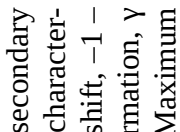

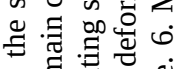

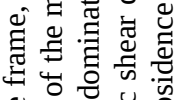

产.

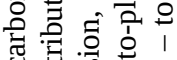

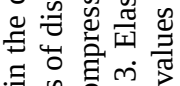

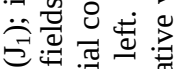

on $\vec{a}$.

目

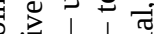

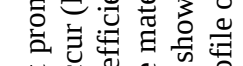

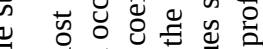

E

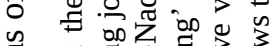

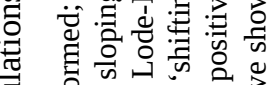

른

에

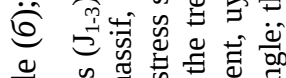

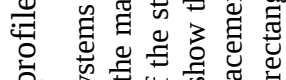

ㄴ.

可

表

등

可

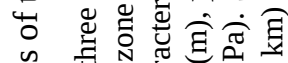

$y$ E

응

낭

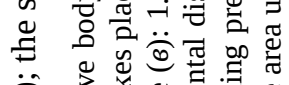

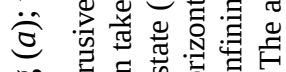

of

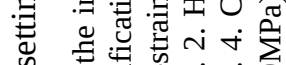

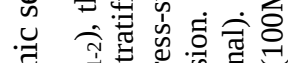

额

垴

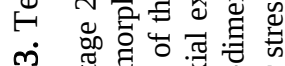

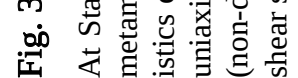

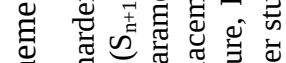

可 0 \% 
(2)

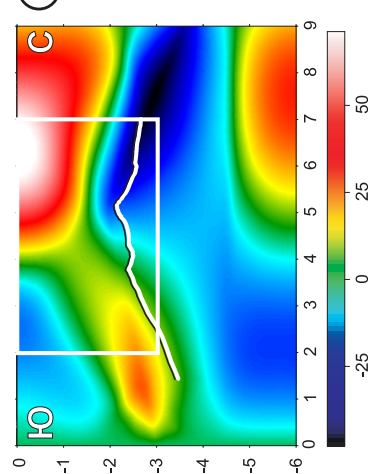

$\ominus$

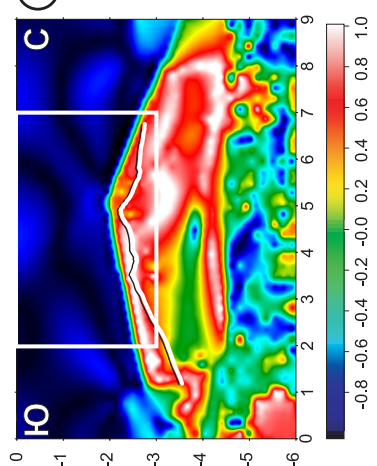

иетен-ətоц 'феоя $\odot$

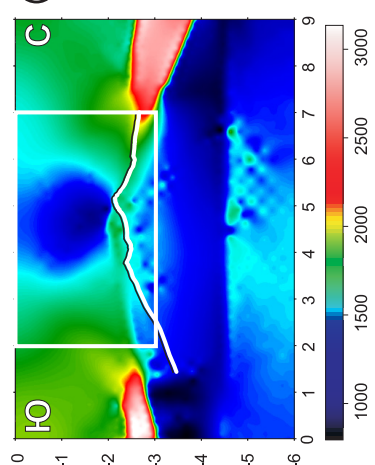

(5)

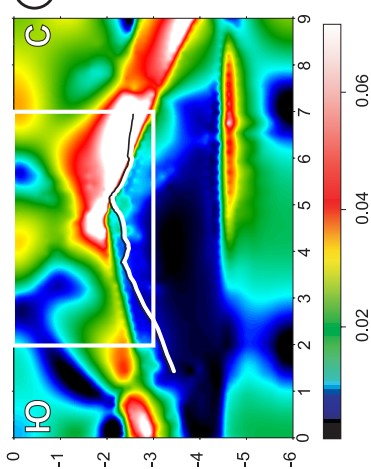

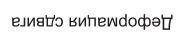

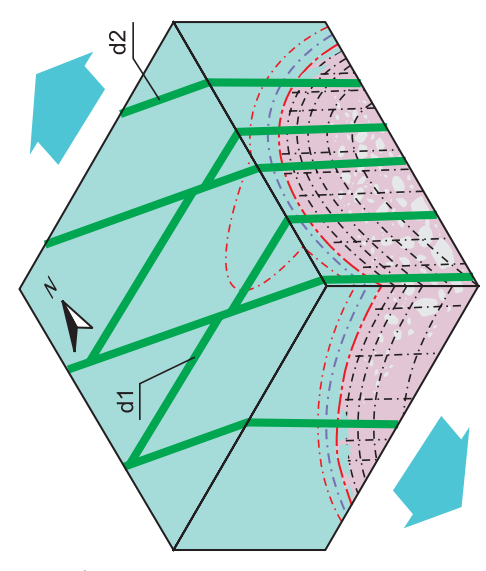

$\sigma$ $\infty$

6

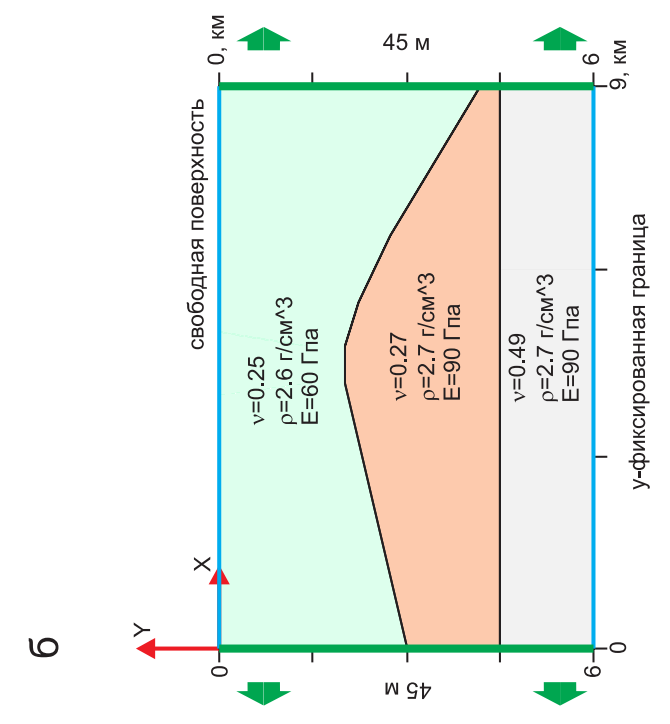

()

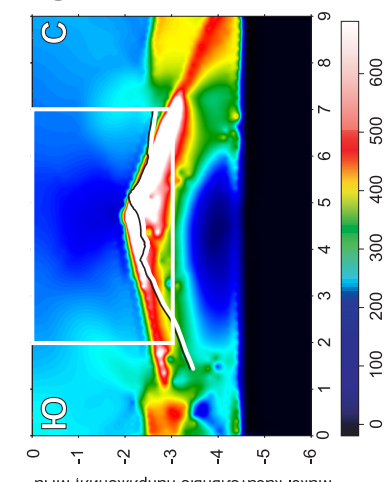

(a)

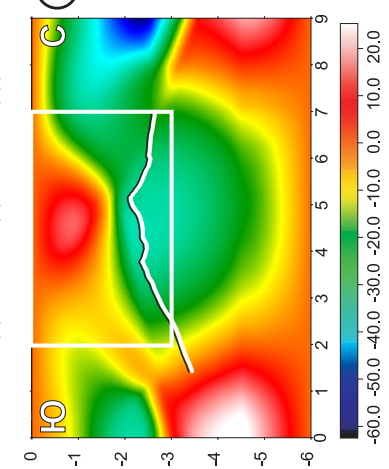

w 'винәтпәшәdəu әІанवчехицdәg

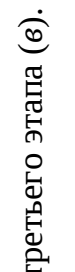

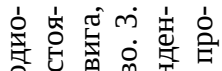

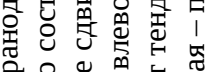

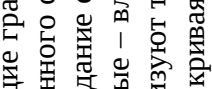

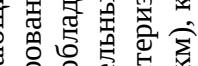

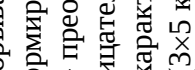

它客: 1

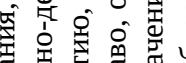

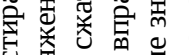

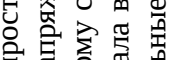

要

त्र

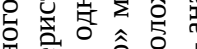

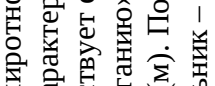

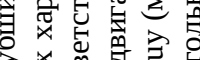

要

空

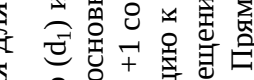

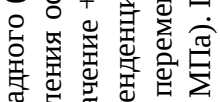

贾

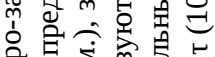

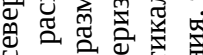

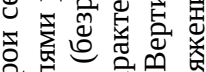

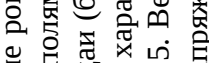

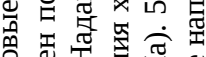

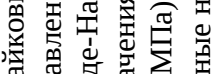

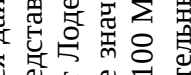

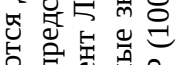

을

6)

空

政

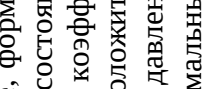

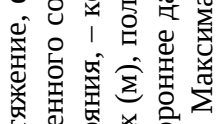

일

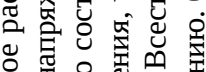

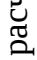

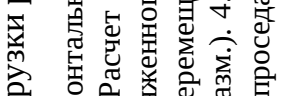

产 on

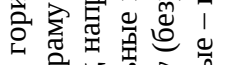

일

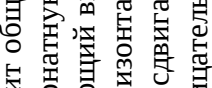

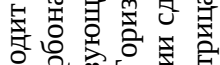

웡

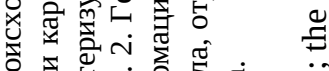

5

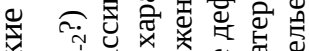

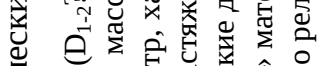

要

$\dot{\nabla}$

ن

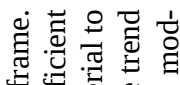

政

뜽.

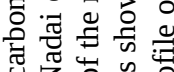

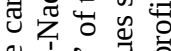

웧

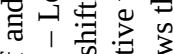

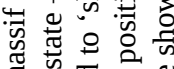

过

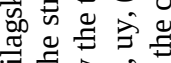

恶

응

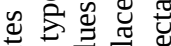

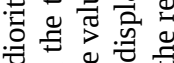

을 을

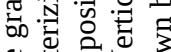

家

m

品

क 3 政

可离数

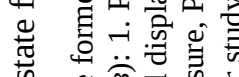

क

政

क

要

○

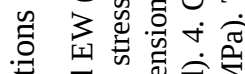

产

可

एक

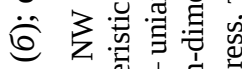

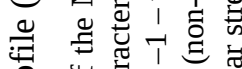

하ㅇㅝㅔ

च 次完

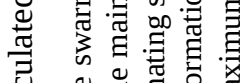

o

ฮ च

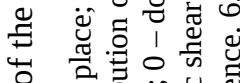

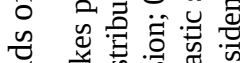

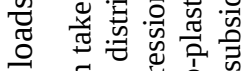

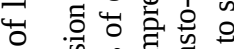

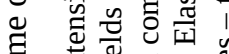

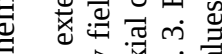

저요.

应

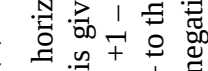

on $\overline{0} 0.0$

善

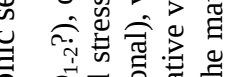

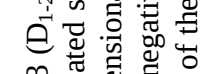

$\leftarrow$

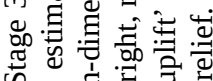

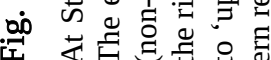


время действия данного тектонического режима не произошло значительного изменения поперечного размера профиля, тем не менее сформировалась структура хрупких нарушений, заполненных интрузивными телами (дайками). Эта стадия обусловлена окончанием поверхностной эрозии.

На четвертой стадии (рис. 5, б) горизонтальное растяжение продолжается. В это же время начинается заполнение депрессии над проседающим центральным включением, ограниченным крупными сбросовыми нарушениями. Упомянутые разломные нарушения и дайки формируют ослабленные зоны для возможных сдвиговых перемещений. В условиях горизонтального растяжения это предполагает создание дополнительных условий для проседания центрального включения вдоль разломных нарушений. Следует отметить, что угол наклона разломных нарушений к вертикали составляет 7-9․ В отличие от геологической модели (рис. $5, a)$, в схеме нагружения (рис. 5, б) для упрощения расчетов не учтены сдвиго-раздвиговые деформации (собственно антиплоский сдвиг) и выведение массива на поверхность (аплифт).

Пятая стадия (рис. 6, б) характеризуется формированием континентальных эффузивных потоков, слепых интрузивных тел кислого состава и продолжением заполнения депрессий. Шестая стадия характеризуется региональным горизонтальным сжатием (рис. 7, б).

В схеме нагружения (рис. 2, б; 7, б) не рассмотрена дальнейшая эволюция структуры интрузива от стадии горизонтального сжатия до современного состояния. Предполагалось, что исследуемая область испытывала вертикальные перемещения глыбового характера без значительных изменений внутри блоков.

\section{3. РЕЗУЛЬТАТЫ МОДЕЛИРОВАНИЯ}

В численной модели рассчитывались следующие параметры напряженно-деформированного состояния среды: коэффициент Лоде-Надаи, деформация сдвига, литостатическое давление, максимальные касательные напряжения, горизонтальные и вертикальные перемещения. Результаты численного моделирования представлены на рис. 2, в, 7, в.

Анализ основных параметров напряженно-деформированного состояния первого этапа показывает, что деформация близка к одноосному сжатию (рис. 2, в). Горизонтальные деформации показывают тенденцию к гравитационному «растеканию» карбонатного тела от центральной части интрузивного массива, тем не менее выделяется область с хорошо выраженными сдвиговыми характеристиками вдоль крутой наклонной северной границы раздела карбонатного фундамента и интрузивного тела. Структурный нижний слой пытается скомпенсировать возникшие напряжения. Достаточно монотонное распределение вертикальных деформаций характеризует однородность воздействия приложенной нагрузки, однако распределение давлений свидетельствует об их повышенных значениях в карбонатном фундаменте вблизи апикальной части интрузива (в этой же области наблюдаются и повышенные максимальные касательные напряжения).

На втором этапе (рис. 3, в) при снятии половины нагрузки можно выделить четкую область преобладания деформации сдвига в карбонатном основании над массивом гранодиоритов. При этом область максимальных значений деформации сдвига над крутой (северной) границей интрузива «перекрывает» область над пологой южной границей, обусловливая асимметрию общего поля сдвиговых деформаций. В остывающей (более сжимаемой) интрузии распределение характеристики напряженного состояния становится менее однородным. Нижняя структурная область попрежнему оказывает компенсирующее воздействие. В горизонтальных перемещениях четко выделяются области различно ориентированных смещений, что может свидетельствовать о тенденции к разделению массива на крупные блоки. Распределение давлений обусловлено снятием равномерной нагрузки и, вероятно, передается интрузивному массиву ввиду предположенной их меньшей прочности - наблюдается стандартная область растяжения (локального разуплотнения в апикальной части массива), прослеживаемая и в поле максимальных касательных напряжений.

Напряжения и деформации третьего этапа (рис. 4, в) обусловливают полное снятие нагрузки от осадочных комплексов вследствие эрозионного размыва осадков и общее горизонтальное растяжение. На третьей стадии распределение коэффициента Лоде-Надаи для анализируемой области показывает резкое различие в режимах тектонической деформации: в карбонатной раме и в нижней части застывшей интрузии наблюдается одноосное растяжение, а верхняя часть гранодиоритовой интрузии подвержена одноосному сжатию. Распределения горизонтальных перемещений свидетельствуют о продолжении гравитационного «растекания» со склонов интрузивного купола.

В отличие от указанной преемственности, в вертикальных перемещениях картина становится далекой от равномерного распределения. Здесь наблюдается чередование областей поднятия с областями проседания, как, например, над центральной частью и в центральной части интрузивного тела. Сдвиговые деформации проявляют наличие значимой аномальной области вдоль северной границы раздела известняков и гранодиоритов. Кроме этого, следует отметить локальные области пониженных значений деформаций сдвига (окрашены темно-синим). Самая большая из них содержит основной объем интрузивного массива. Распределения давлений указывают на формирование локальной области низких давлений в центральной части карбонатной рамы. Формирование «ячеистой» структуры в нижнем модельном слое указывает на развитие здесь пластического течения. Касательные напряжения 
(2)

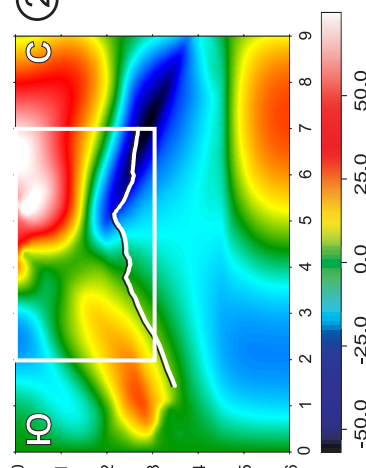

w 'винәтпюшәdəu әянवцецновиdо」

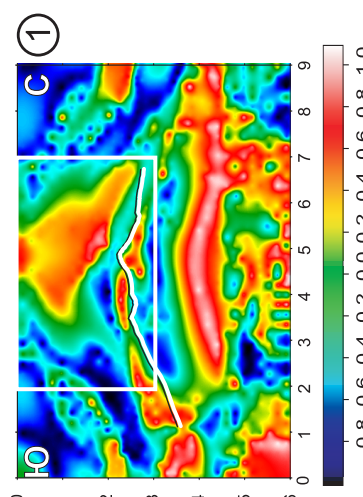

иенен-әтоц -феоя $\odot$

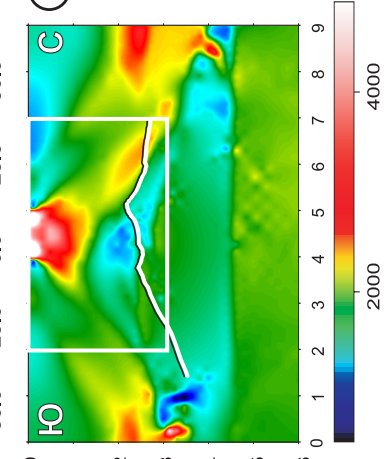

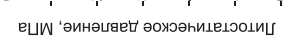

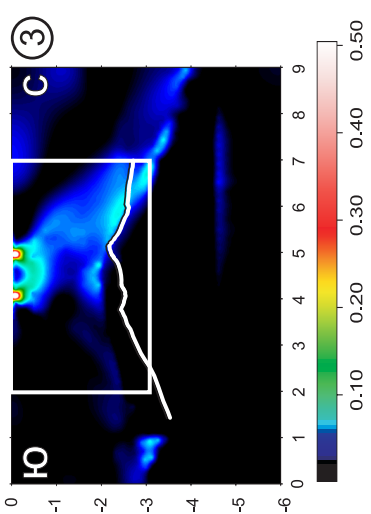

$\infty$

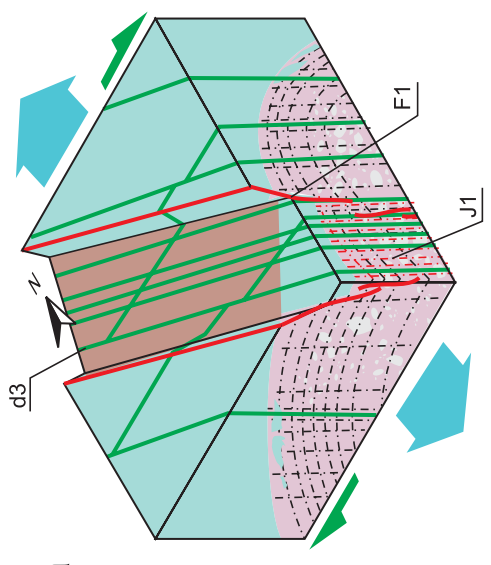

$\sigma$

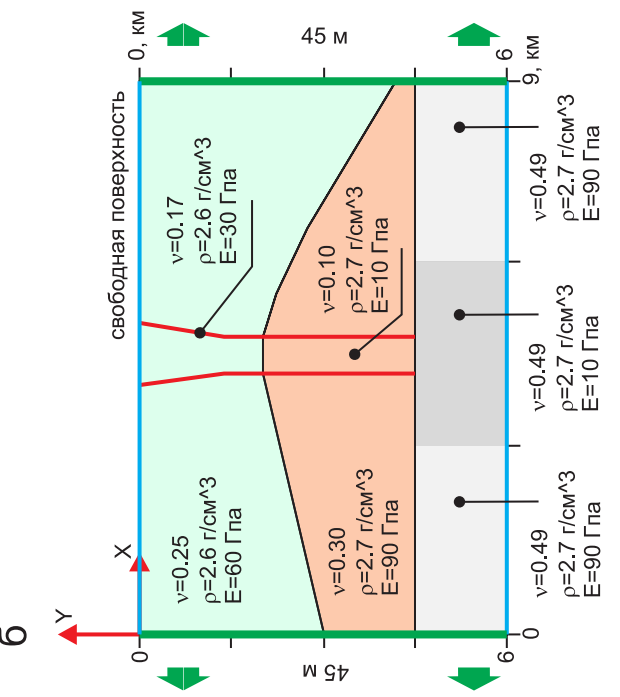

()

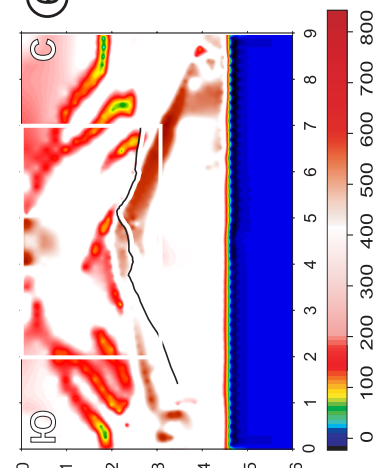

(6)

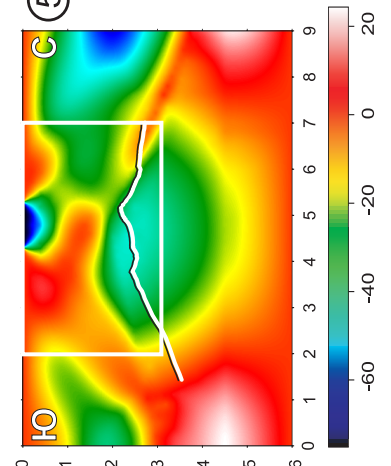

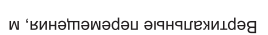

(3)

\section{6}

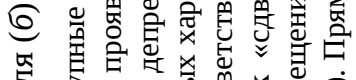

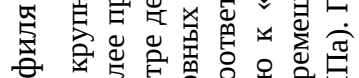

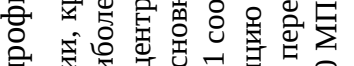

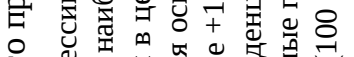

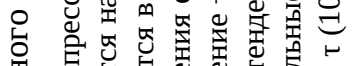

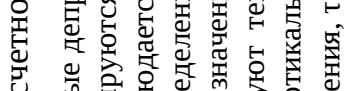

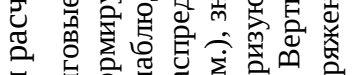

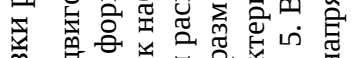

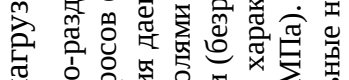
垔

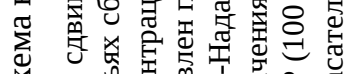

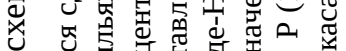

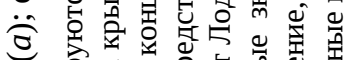

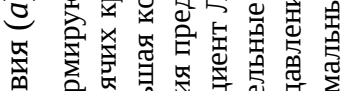

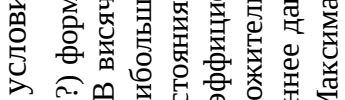

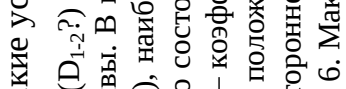

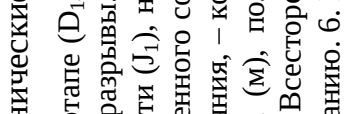

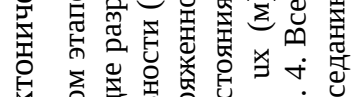

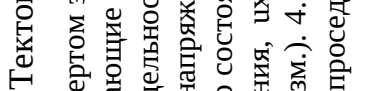

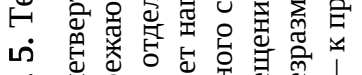

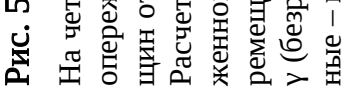

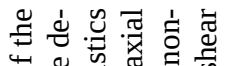

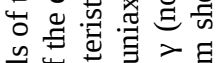

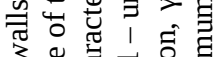

on

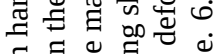

$\Xi . \Xi \cong . \Xi$

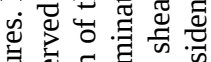

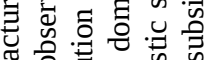

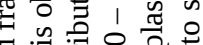

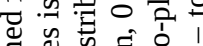

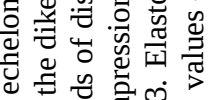

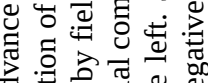

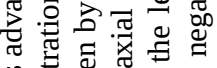

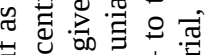

要

.

(0)

จ

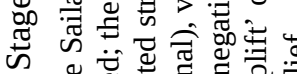

क

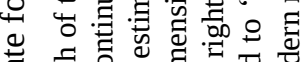

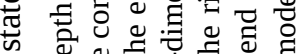

W

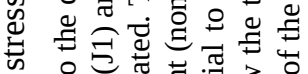

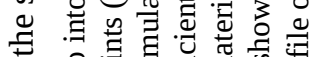

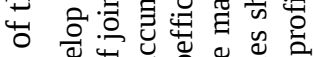

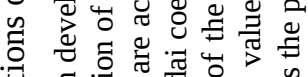

沿

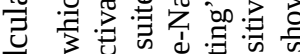

च 정

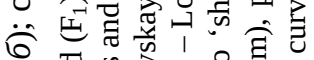

의

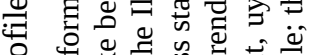

政

完

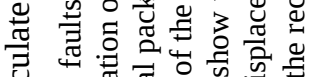

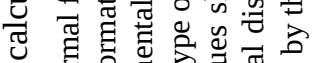

웜

t

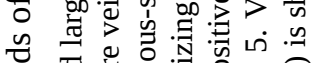

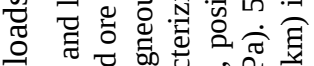

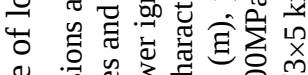

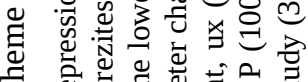

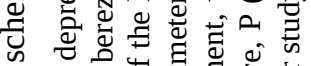

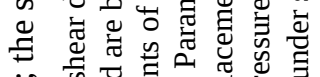

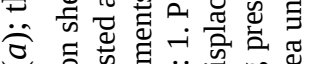

क्ष

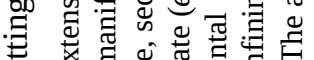

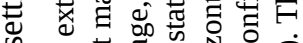

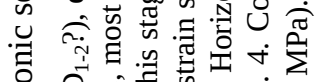

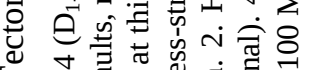

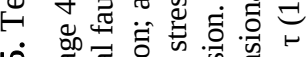

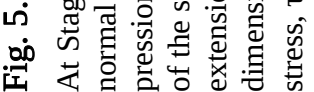


()

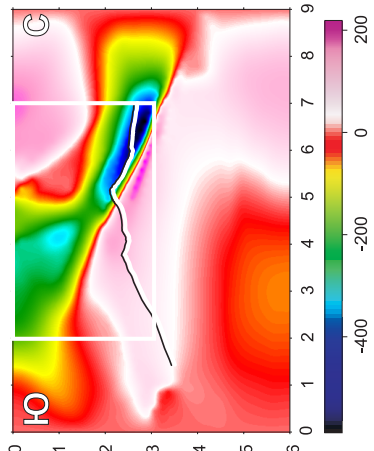

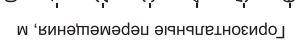

$\odot$

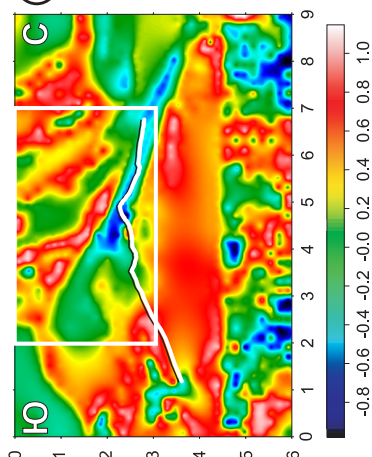

nетен-әtо山 'феок $\odot$

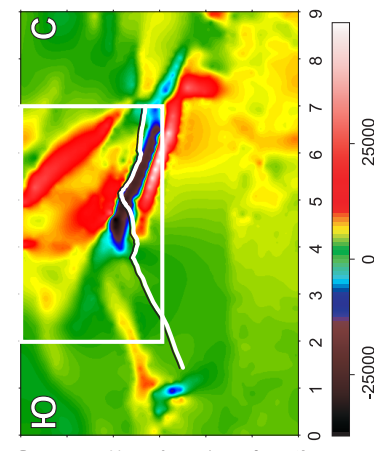

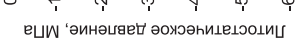

())

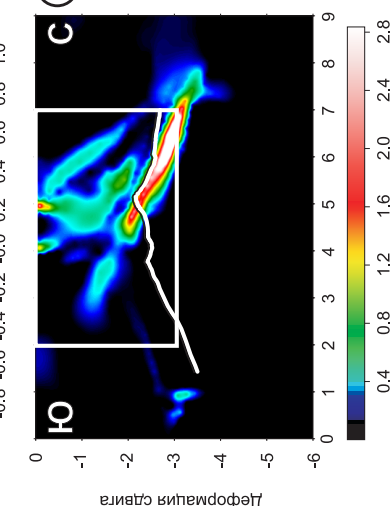

$\infty$

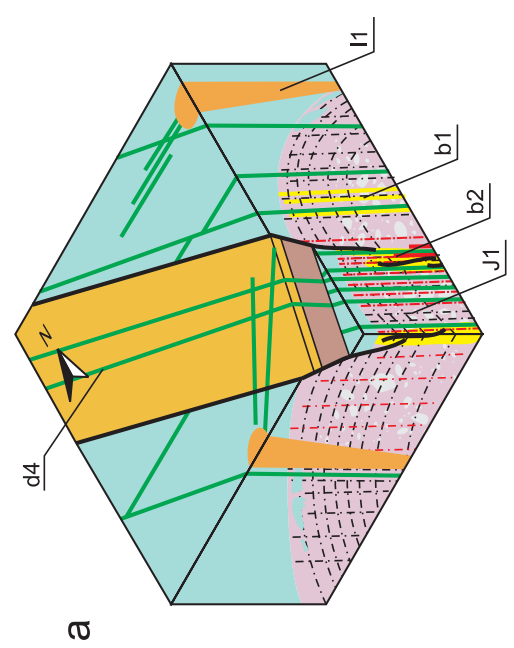

10

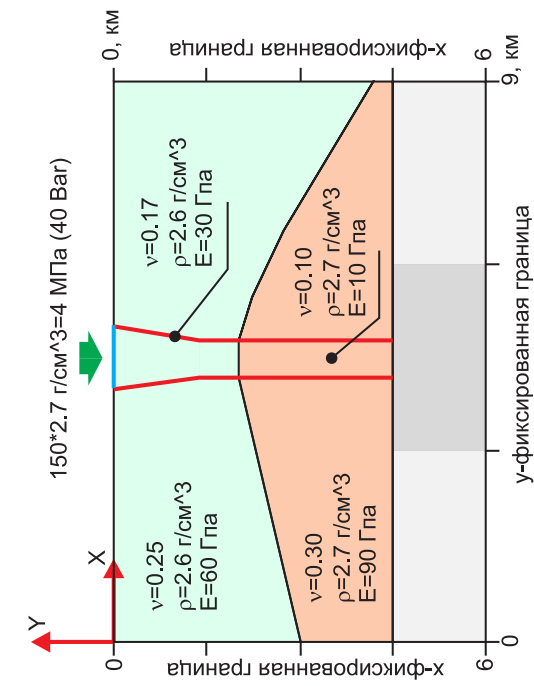

(a)

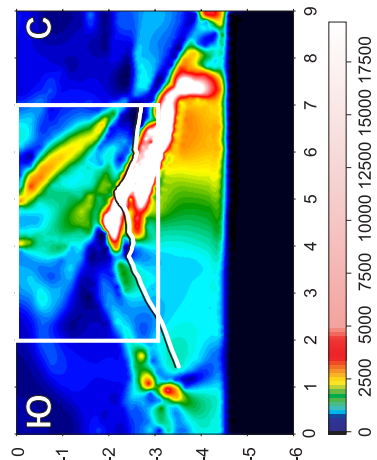

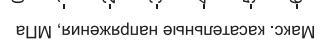

(b)

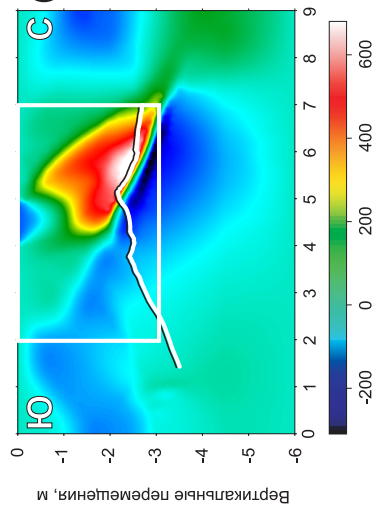

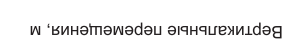

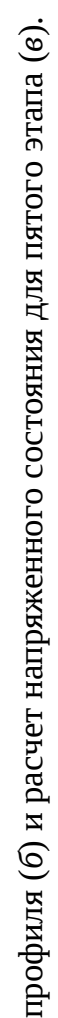

ש

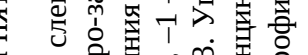

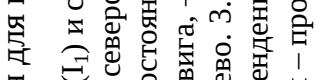

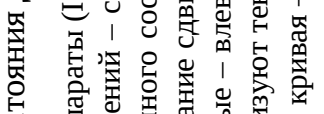

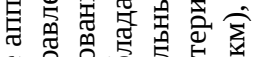

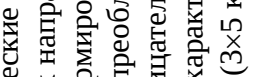

兽各

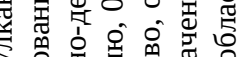

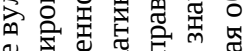

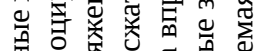

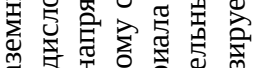

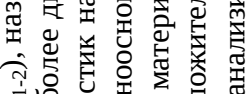

(2)

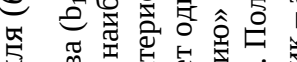

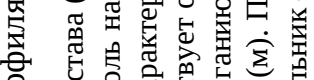

ठ ठ

음

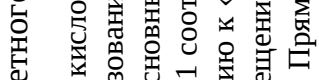

す

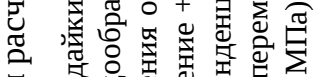

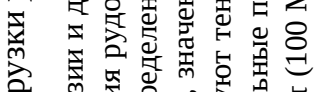

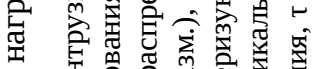

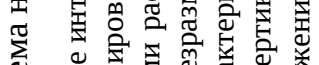

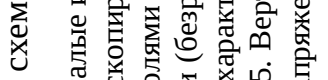

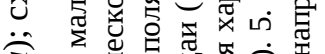

(

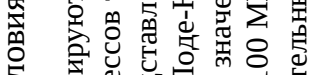

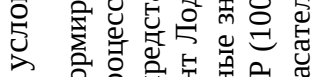

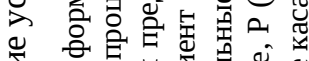

疍

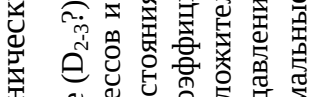

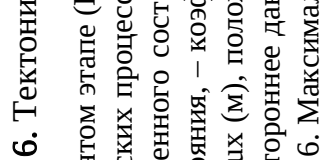

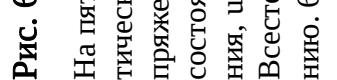

离离

西䒕苛泀目

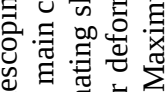

总苛䒕

능 은 出

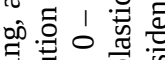

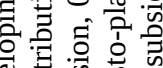

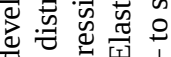

๑ ठ त्:

등

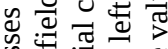

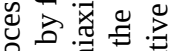

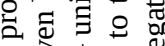

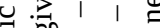

चิ

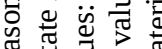

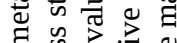

(0)

ه

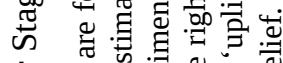

ธี ช

ชัّ

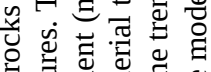

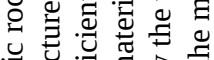

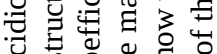

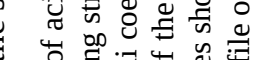

प一

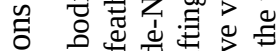

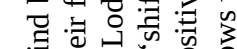

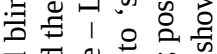

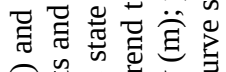

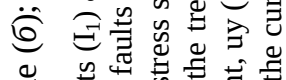

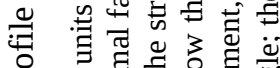

苞

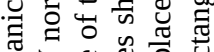

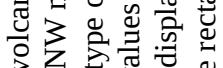

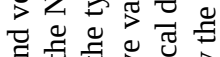

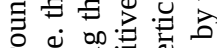

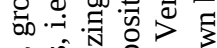

กิ่

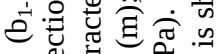

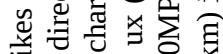

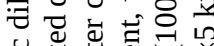

.

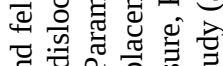

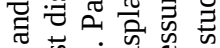

क चै क्ञ

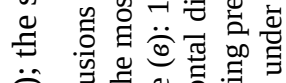

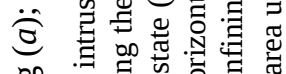

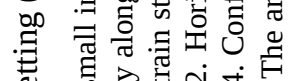

的光数

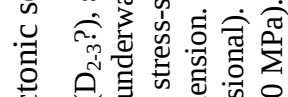

ป

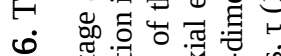

ஹ่ 
()

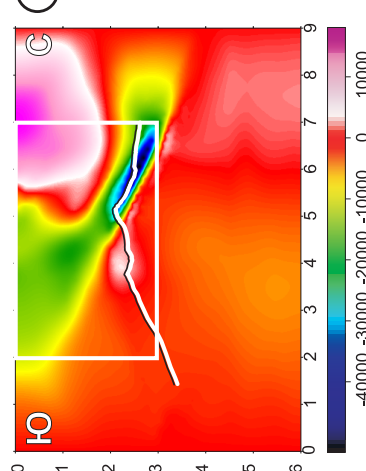

$\Theta$

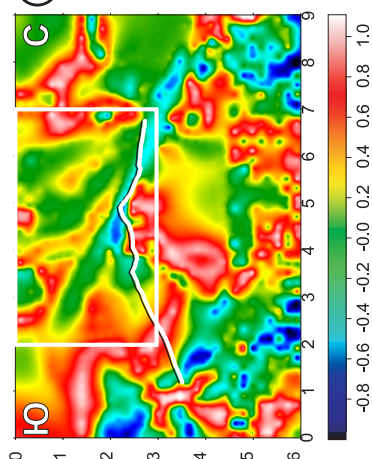

netreh-ətou 'феок $\odot$

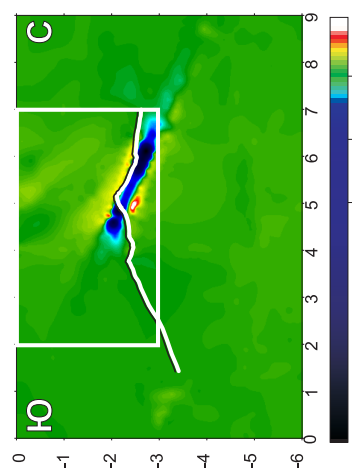

(9)

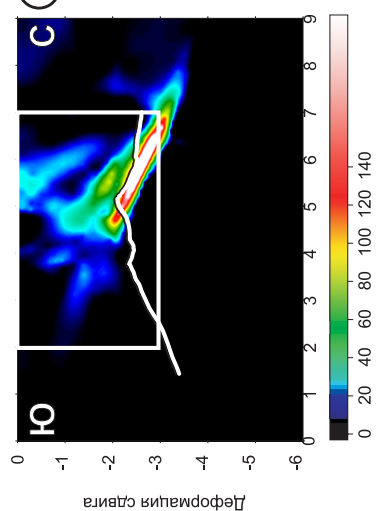

$\infty$

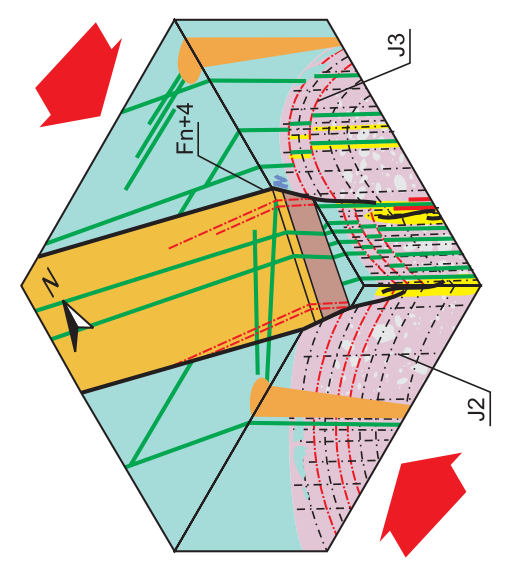

$\sigma$

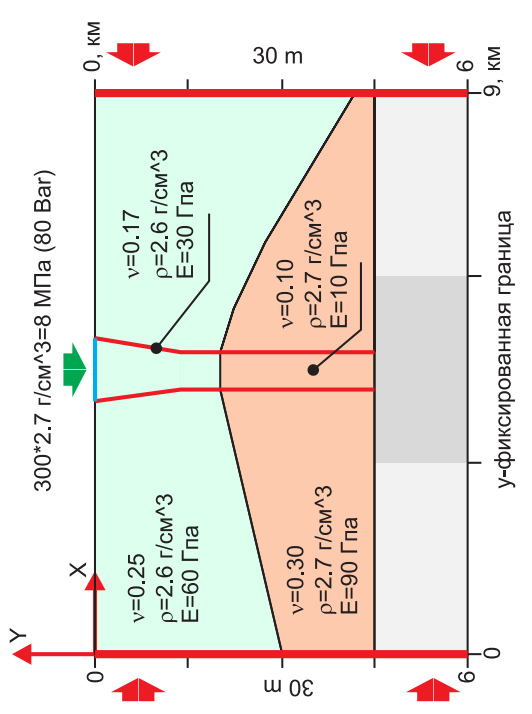

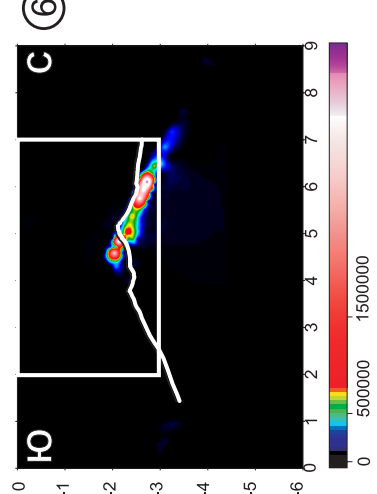

(b)

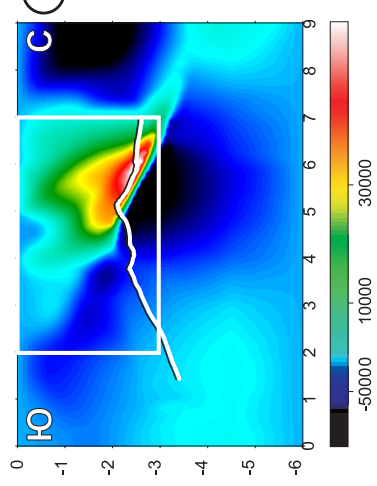

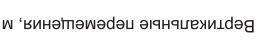

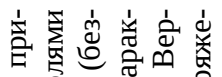

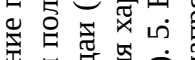

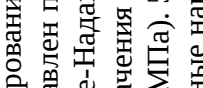

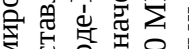

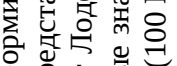

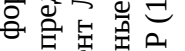

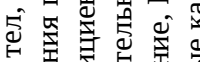

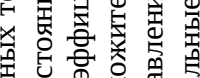
。 운

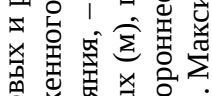

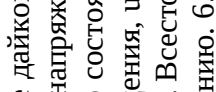
壳

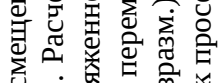

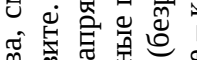

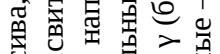

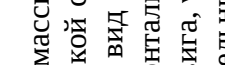

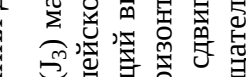

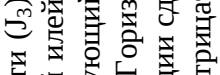
志产害

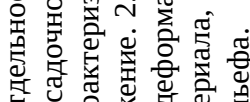

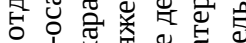

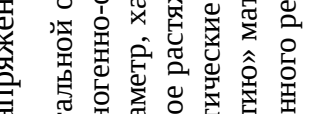

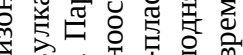

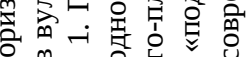

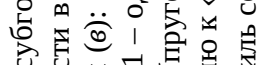

(2)

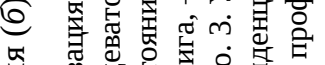

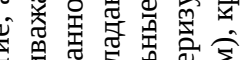
雪

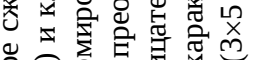

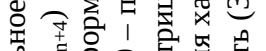

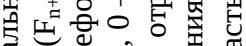

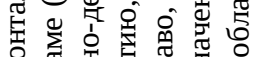

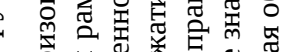

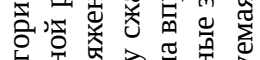

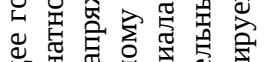

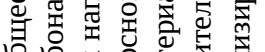

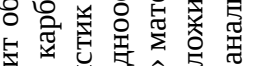

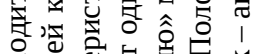

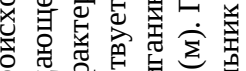

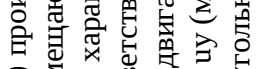

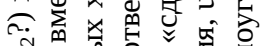

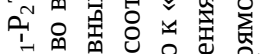
U 焉志

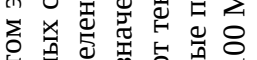
-

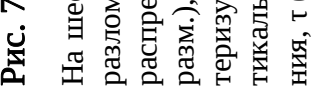

Ð

$\Xi$ 常 $气$ 出

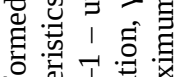

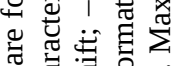

究

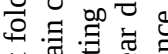

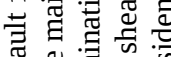

昰导言㻤

ख़

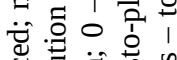

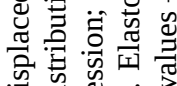

$\because$ :

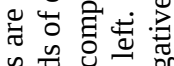

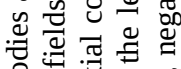

응. 워

宁 1

के

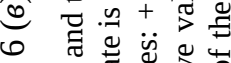

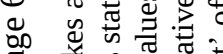

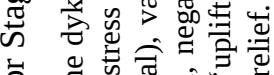

क्ष

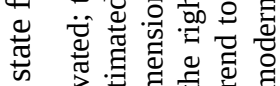

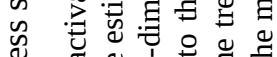

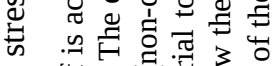

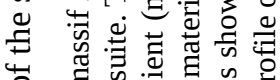

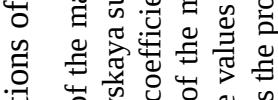

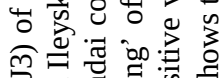

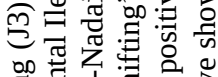

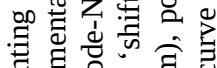

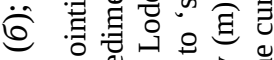

임

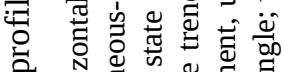

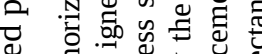

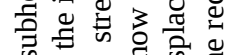

क

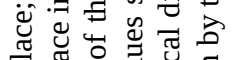

군 $\frac{\pi}{2}$ 光

过

焉

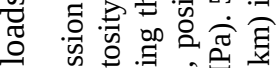

पे

๑

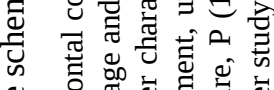

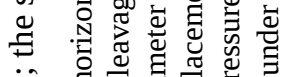

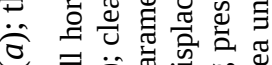

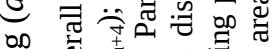

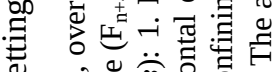

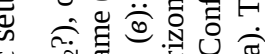

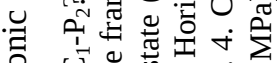

过苛

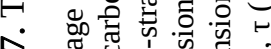

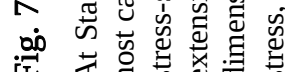


обнаруживают максимум значений в протяженной области внутри гранодиоритного массива вдоль его северной границы раздела с карбонатными породами.

Четвертая стадия (рис. 5, в) обусловлена началом проседания центральной части карбонатной рамы вследствие горизонтального растяжения. Заполнение образовавшейся депрессии вулканогенно-осадочными породами выражалось в задании дополнительных «давящих» краевых условий по верхней границе центральной отдельности. Линеаризованные разломные тела, обрамляющие центральную отдельность, представляют собой достаточно тонкие области преобладания сдвиговых деформаций, а процесс деформирования в них аналогичен «слайд-элементу».

Отметим, что по распределению коэффициента Лоде-Надаи область одноосного сжатия имеет асимметричное расположение и включает центральную часть массива, а также линейную область вдоль экзоконтакта северной границы гранодиоритов. Области растяжения здесь линеаризованы и чередуются с областями, близкими к состоянию чистого сдвига. Распределения горизонтальных перемещений в целом сохраняют тенденцию к растеканию по интрузивному куполу. Вертикальные напряжения показывают хорошее совпадение расположения проседающей центральной отдельности с областью выше массива, выделенной на предыдущей стадии, что также подтверждает преемственность в деформировании.

Кроме этого, максимальные деформации сдвига выделяют в единое тело центральную часть и область вдоль правой границы раздела карбонатов и гранодиоритов (внутри карбонатного массива). Завышенные значения на концах разломных тел не несут в данном случае физического смысла. Касательные напряжения обнаруживают хорошо линеаризованные структуры максимальных значений, что, очевидно, может быть связано с образованием системы наклонных разломов, сопряженных с границей раздела интрузивного массива.

На пятом этапе (рис. 6, в) напряженно-деформационные характеристики показывают однородное состояние внутри массива и сильную анизотропию на северном экзоконтакте Сайлагского массива. В распределении коэффициента Лоде-Надаи видно, что линеаризованные области сдвиго-сжатия чередуются с областями одноосного сдвига именно в карбонатной раме. Самое значительное растяжение обусловлено крутопадающей северной границей раздела интрузивного тела. Эта особенность по-прежнему хорошо просматривается в распределении горизонтальных перемещений. Вертикальные перемещения обозначают область субвертикального воздымания, имеющую клиновидную наклонную структуру.

Области, полученные на следующих трех распределениях: угловой деформации, литостатического давления и максимальных касательных напряжений, имеют общие закономерности. Основная особенность - нали- чие структуры сдвигового деформирования вдоль северной границы карбонаты - гранодиориты и сопутствующих двух структур с увеличивающимся углом падения (впервые проявленных на предыдущем этапе).

На шестом этапе (рис. 7, в) большее значение приобретают деформации сдвига вдоль линеаризованных структур, выявленных на пятом этапе (из распределения коэффициента Лоде-Надаи). Распределение компонент перемещений показывает хорошую преемственность по отношению к предыдущей стадии. Распределения анализируемых параметров напряженного состояния и поля деформаций показывают образование макроразрыва вдоль северной границы раздела карбонаты - гранодиорит.

Из графика распределения вертикальных перемещений видно механическое расслаивание на границе гранодиориты-карбонаты, а из графиков деформации сдвига и литостатического давления - расположение в карбонатах линейной области максимальных деформаций сдвига при низких литостатических напряжениях. На графике горизонтальных перемещений наблюдается резкое различие в кинематике висячего карбонатного крыла разрывного нарушения и гранодиоритов в лежачем крыле, а также слабая анизотропия в характере распределения внутри массива, что фактически подтверждается геологическими наблюдениями за смещением даек и слабовыраженных пологих зон сдвига в Сайлагском массиве. Следует отметить, что вертикальные перемещения центральной области над массивом могут быть связаны с гравитационным взаимодействием (тектоническим «течением») геоматериала при образовании макроразрыва вдоль северной границы раздела карбонаты - гранодиорит.

\section{4. ГЕОЛОГИЧЕСКАЯ ИНТЕРПРЕТАЦИЯ РЕЗУЛЬТАТОВ}

Уже на первых этапах эволюции структуры (внедрение и остывание массива) формируются две области локальных неоднородностей в гранодиоритовом массиве и на его границах (см. рис. 2, в, 3, в). Первая область протягивается от апикальной части интрузивного массива вертикально вниз и отражает тенденцию разделения остывающего массива на блоки, границы которых могут сопоставляться с крупными разрывными нарушениями в интрузивном массиве. Таким разрывным нарушением может служить, например, Вишневый разлом, относительно которого пологие трещины отдельности (остывания массива) падают в противоположные стороны от разлома. Наблюдаемые в Сайлагском массиве Радужный и Южный разломы, параллельные Вишневому разлому, не выделяются в полях напряженно-деформированного состояния и, вероятно, отражают особенности строения массива, не учитываемые в модели.

Вторая область связана с северной границей массива, которая имеет более крутое падение. Этой сложной 
границе соответствует мощная зона бластокатаклазитов в карбонатных породах на границе с интрузивным телом. Как видно из результатов моделирования, эта неоднородность является наиболее долгоживущей из всех линейных и площадных структурных особенностей эволюционной модели (рис. 3, в; 7, в).

На третьем этапе (горизонтального растяжения) продолжается формирование внутри массива вертикальной зоны, обусловленной гравитационным «растеканием» в центральной части массива (рис. 4, в). Следует отметить, что внедрение даек в эту стадию происходит вдоль ослабленных зон (вертикальных трещин отдельности) в центральной части массива, сформировавшихся во второй этап.

Другой важной особенностью напряженного состояния на данном этапе является вертикальное механическое расслоение интрузивного массива, выраженное в резкой смене коэффициента Лоде-Надаи и максимальных касательных напряжений (рис. 4, в). Границы резкой смены указанных параметров соотносятся с пологозалегающими зонами сдвига, параллельными субгоризонтальной (концентрической) отдельности интрузива. Результаты наблюдений над кинематическими индикаторами в этих зонах сдвига подтверждают гравитационное «растекание» горной породы от центра массива.

На четвертом этапе важным результатом является тот факт, что формирование вулканогенно-осадочных депрессий не оказывает сколько-нибудь значительного влияния на напряженно-деформированное состояние интрузивного массива, но активно влияет на изменение поля напряжений и деформаций экзоконтакта северной границы массива, выраженное в формировании сопряженных разломов, падающих от центра массива (рис. 5, в).

Таким образом, наиболее вероятна модель формирования вулканотектонических депрессий не как вновь образующихся структур растяжения земной коры, а как наследующих разрушенные апикальные части интрузивных массивов. Это отчасти подтверждается геологическими наблюдениями за контактами илейской, иркутной свит и Сайлагского массива в его западной части. Второй важной особенностью является преемственность вертикальной неоднородности массива, выраженной в резкой смене коэффициента Лоде-Надаи (см. рис. 4,$8 ; 5,8)$.

На пятом и шестом этапах во вмещающей карбонатной раме формируются линейные неоднородности, которые могут быть сопоставлены со значимыми разломными нарушениями или проводящими каналами для миграции флюидов (рис. 6, в; 7, в), сочленяющимися с выделенной на ранних этапах линейной неоднородностью вдоль крутой северной границы массива.

Как уже отмечалось выше, компьютерное моделирование Сайлагского массива проводилось с целью уточнения развития структур интрузива в связи с его золотоносностью. Если формирование оруденения зо- лотопорфирового типа происходило на втором этапе (при застывании массива), то апикальная часть массива, очевидно, являлась благоприятной областью для формирования оруденения штокверкового типа (модель прожилково-вкрапленной минерализации). Однако основные рудные зоны Коневинского месторождения связаны с разломами, выполненными дайковыми телами и кварцевыми жилами. В связи с этим в геологической модели важное место в образовании рудной минерализации отводилось именно этапу внедрения даек и времени формирования вулканогенно-осадочной депрессии, заполненной отложениями илейской свиты.

Проведенные расчеты показали, что крутопадающие разрывные нарушения, к которым приурочены дайки и кварцевые жилы, могли сформироваться еще на стадии остывания Сайлагского массива, под влиянием «гравитационного растекания» геоматериала (рис. 3, в). Таким образом, дайковые тела и кварцевые жилы заполняли ослабленные линейные зоны, форма и ориентировка которых были сформированы еще на предыдущих этапах. Более того, дополнительная нагрузка при образовании вулканогенно-осадочных депрессий не показала значительных изменений в характере распределения параметров поля напряжений и деформаций в массиве (рис. 4, в; 5, в).

В связи с этим структурный облик рудного поля определяют не отдельные тектонические этапы, а этапы остывания массива и формирование сдвиго-раздвиговой депрессии в механически ослабленной апикальной части интрузивного массива.

Еще одной важной особенностью, выявленной численным моделированием для третьего и четвертого этапов (горизонтального растяжения), является механическая «расслоенность» в массиве гранодиоритов, выраженная в чередовании узких областей одноосного растяжения и одноосного сжатия (рис. 4, в; 5, в). Иными словами, если на этапе горизонтального растяжения происходило формирование рудной системы, то вертикальный размах оруденения был ограничен высотой области одноосного растяжения механической «расслоенности» массива.

\section{5. ЗАКЛЮЧЕНИЕ}

Таким образом, проведенное моделирование не противоречит разработанной геологической модели формирования структур Сайлагского массива и при этом показывает возможность возникновения линейных и площадных неоднородностей под определяющим воздействием гравитационных эффектов и процессов поверхностной эрозии, не описываемых в геологической модели.

Следует отметить, что характерные времена рассмотренных геологических процессов достаточно велики, чтобы пренебречь влиянием метаморфических 
процессов и вязкой релаксации. Тем не менее мы полагаем, что в рамках использованной схемы расчетов остаточные пластические деформации релаксируют на более коротких временах, а указанные эффекты могут быть качественно учтены в изменении соответствующих механических и прочностных характеристик геоматериалов.

Полученные величины характеристик напряженнодеформированного состояния целесообразно рассматривать только как качественную иллюстрацию. Однако результаты численного моделирования эволюционного формирования геологической структуры Сайлагского массива можно использовать как опорные для исследования других интрузивных массивов, несущих определенные черты сходства в эволюционном развитии. К таким результатам относятся следующие особенности напряженно-деформационного поля: формирование долгоживущих линейных зон сдвига на крутопадающих границах интрузивных тел; формирование субвертикальных разрывных структур над указанной зоной сдвига в условиях вертикальной нагрузки интрузива; механическая «расслоенность» интрузивного тела в условиях горизонтального растяжения, а также локальные области разрушения в апикальной и надкупольной частях интрузивов.

\section{6. ЛИТЕРАTУРА / REFERENCES}

Belov S.V., 1993. The tectonophysical model of the ore-bearing systems: an intrusion and its roof. Geotektonika 2, 64-72 (in Russian) [Белов С.В. Тектонофизическая модель рудоносной системы: интрузив и его кровля // Геотектоника. 1993. № 2. C. 64-72].

Fedotova A.A., Khain E.V., 2002. Tectonics of the South Eastern Sayan and Its Position in the Ural-Mongolian Belt. Nauchny Mir, Moscow, 171 p. (in Russian) [Федотова А.А., Хаин E.В. Тектоника юга Восточного Саяна и его положение в Урало-Монгольском поясе. М.: Научный мир, 2002. 171 с.].

Gromov P.A., Voytenko V.N., Yakubovskaya A.O., Goneger A.V., 2011. The evolution of the tectonic stress field of the Konyovinskoe deposit from results of structural-tectonophysical and microstructural analyses. In: Proceedings of the Second Youth Tectonophysical Workshop. Moscow, Moscow State University, 65-68 (in Russian) [Громов П.А., Войтенко B.Н., Якубовская А.О., Гонегер А.В. Эволюция поля тектонических напряжений Конёвинского месторождения по результатам структурно-тектонофизического и микроструктурного анализов // Материалы второй молодежной тектонофизической школы-семинара. М.: МГУ, 2011. С. 65-68].

Pogorelov V.V., Koneshov V.N., Rebetskiy Yu.L., 2010. Numerical modelling of stress state for western Sunda subduction region. Bulletin of Kamchatka Regional Association "Educational-Scientific Center". Earth Sciences 1 (15), $174-192$.

Rebetsky Yu.L., 2008. Mechanism of tectonic stress generation in the zones of high vertical movements. Fizicheskaya mezzomekhanika 11 (1), 66-73 (in Russian) [Ребецкий Ю.Л. Механизм генерации тектонических напряжений в областях больших вертикальных движений // Физическая мезомеханика. 2008. Т. 11. № 1. С. 66-73].

Roshchektaev P.A., Mironov A.G., Doroshkevich G.I., 2000. Gold of Buryatia. Publishing House of BSC, SB RAS, UlanUde, Book 1, 463 p. (in Russian) [Рощектаев П.А., Миронов А.Г., Дорошкевич Г.И. Золото Бурятии. Улан-Удэ: Издво БНЦ СО РАН, 2000. Книга 1. 463 с.].

Vlasov A.N., Yanovsky Yu.G., Mnushkin M.G., Popov A.A., 2004. Solving geomechanical problems with UWay FEM package. In: Iu V.P. (Ed.), Computational methods in engineering and science. Taylor \& Francis, London, p. 453-461.

Zhmodik S.M., Mironov A.G., Bobrik O.M., Zhmodik A.S., Shadrina S.V., Guntypov B.B., 2006. Two types of gold-porphyritic systems of the Eastern Sayan. In: Proceedings of the 3rd All-Russia Symposium "Gold of Siberia and the Far East: Geology, Geochemistry, Technology, Economy, Ecology”. SVNTS, FEB RAS, Magadan, 74-87 (in Russian) [Жмодик С.М., Миронов А.Г., Бобрик О.М., Жмодик А.С., Шадрина С.В., Гунтыпов Б.Б. Два типа золото-порфировых систем Восточного Саяна // Труды III Всероссийского симпозиума “Золото Сибири и Дальнего Востока: геология, геохимия, технология, экономика, экология”. Магадан: СВНЦ ДВО РАН, 2006. С. 74-87].

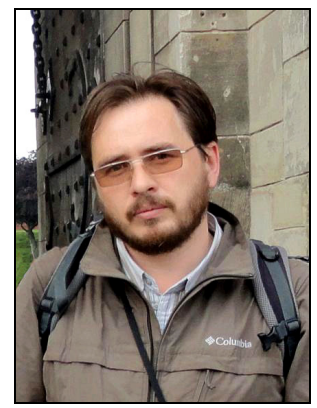

Войтенко Вячеслав Николаевич, канд. геол.-мин. наук, доцент Геологического факультета СПбГУ Санкт-Петербургский государственный университет

199034, Санкт-Петербург, Университетская набережная, 7-9, Россия

Тел.: 3282000; $ه$ e-mail:v.voitenko@spbu.ru

Voytenko, Viacheslav N., Candidate of Geology and Mineralogy, Associate Professor Of Geological Department Saint Petersburg State University

7-9 Universitetskaya nab., Saint Petersburg 199034, Russia

Tel.: 3282000; $₫$ e-mail: v.voitenko@spbu.ru 


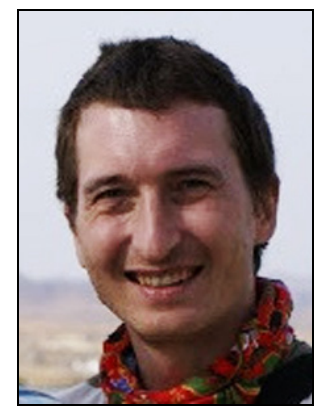

Погорелов Виталий Викторович, канд. физ.-мат. наук, ученый секретарь ИФЗ РАН Институт физики Земли им. О.Ю. Шмидта РАН

123995, ГСП-5, Москва Д-242, ул. Большая Грузинская, 10, Россия

Тел.: +7(499)7662655; e-mail: vvp@ifz.ru

Pogorelov, Vitaliy V., Candidate of Physics and Mathematics, Scientific Secretary IPE RAS

The Schmidt Institute of Physics of the Earth RAS

10 Bol'shaya Gruzinskaya street, Moscow D-242 123995, GSP-5, Russia

Tel.: +7(499)766-2655 ; e-mail: vvp@ifz.ru

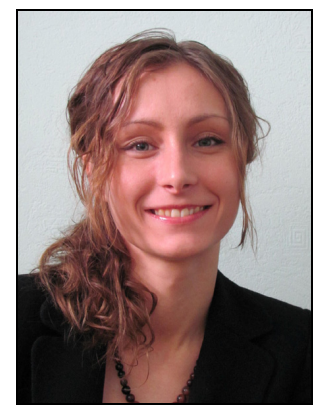

Якубовская Анна Олеговна, старший геолог

ООО "Хужир Энтерпрайз"

670031, Улан-Удэ, ул. Терешковой, 2В, Россия

Тел.: +7(3012)455622; e-mail: mail@hooszhir.ru

Yakubovskaya, Anna O., Senior Geologist

Hoozhir Enterpise LLC

2V Tereshkova street, Ulan-Ude 670031, Russia

Tel.: +7(3012)455622; e-mail: mail@hooszhir.ru

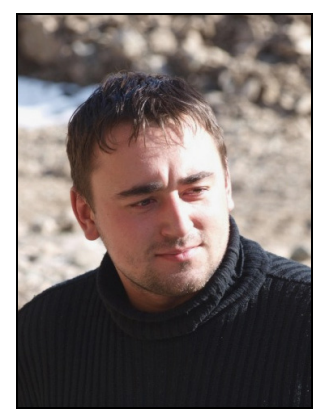

Гонегер Анатолий Викторович, старший геолог ООО "Хужир Энтерпрайз"

670031, Улан-Удэ, ул. Терешковой, 2В, Россия Тел.: +7(3012)455622; e-mail: mail@hooszhir.ru

Goneger, Anatoly V., Senior Geologist

Hooszhir Enterpise LLC

2V Tereshkova street, Ulan-Ude 670031, Russia

Tel.: +7(3012)455622; e-mail: mail@hooszhir.ru 